Energy Technology Strategies for Carbon Dioxide Mitigation and Sustainable Development

K. Riahi

R.A. Roehrl

RR-01-04

March 2001 


\section{Energy Technology Strategies for Carbon Dioxide Mitigation and Sustainable Development}

K. Riahi and R.A. Roehrl

RR-01-04

March 2001

Reprinted from Environmental Economics and Policy Studies, 3(2):89-123 (2000). 
Research Reports, which record research conducted at IIASA, are independently reviewed before publication. Views or opinions expressed herein do not necessarily represent those of the Institute, its National Member Organizations, or other organizations supporting the work.

Reprinted with permission from Environmental Economics and Policy Studies, 3(2):89-123 (2000). Copyright (c) 2000 Springer-Verlag.

All rights reserved. No part of this publication may be reproduced or transmitted in any form or by any means, electronic or mechanical, including photocopy, recording, or any information storage or retrieval system, without permission in writing from the copyright holder. 


\title{
Energy technology strategies for carbon dioxide mitigation and sustainable development
}

\author{
Keywan Riahi and R. Alexander Roehrl \\ Environmentally Compatible Energy Strategies (ECS), International Institute for Applied \\ Systems Analysis (IIASA), Schlossplatz 1, A-2361 Laxenburg, Austria \\ e-mail: riahi@iiasa.ac.at, roehrl@iiasa.ac.at
}

Received: January 5, 2000 / Accepted: March 31, 2000

\begin{abstract}
This paper analyzes a set of global energy-economic development scenarios for the $21^{\text {st }}$ century. The set includes non-climate-policy scenarios that are part of the recent Special Report on Emissions Scenarios (SRES) of the Intergovernmental Panel on Climate Change (IPCC). We apply climate policies to some of these scenarios to achieve stabilization of atmospheric $\mathrm{CO}_{2}$ concentrations at 550 parts per million by volume (ppmv). In particular, we analyze the robustness of technology portfolios under a wide range of possible future socioeconomic and technological outcomes. Clearly, the baseline assumptions determine the choice and costs of optimal emissions mitigation portfolios. The robustness analysis suggests that traditional electricity generation technologies based on fossil fuels are phased-out across all scenarios by 2100 , with gas combined-cycle bridging the transition to more advanced fossil and zero-carbon technologies. Hydrogen fuel cells dominate the power sector in the sustainable development scenarios. In the transport sector, oil products will be phased-out but their future substitutes remain uncertain. Policies should preferably target a combination of sustainable development and accelerated technological change.
\end{abstract}

Key words Energy-economic scenarios - Emissions mitigation - Sustainable development Energy technology strategies $\cdot$ IPCC SRES

\section{Introduction}

Mankind is faced with the profound challenge that its economic activities and resulting emissions of gases might lead to global warming, with significant environmental and economic impacts for our planet. Consistent with the potentially enormous economic magnitude of the climate change problem for future generations, many different types of aggregate macroeconomic analyses have been conducted in recent years (see, e.g., EMF14 1994; Wigley et al. 1996), mainly to help in designing optimal environmental tax strategies. On the other hand, the historical experience of the last 200 years since the beginning of industrialization 
indicates that technological innovations and the speed of technology diffusion have driven economic growth, and vice versa (Barro and Sala-I-Martin 1995; Maddison 1993). New technological developments have helped to overcome the then current environmental and social problems, but in most cases they have also caused new kinds of challenges. In any case, energy technologies have proven to be powerful drivers of environmental change.

To design climate policies targeted at specific energy technology clusters, we need to understand how well different technology portfolios might do in the next century, in economic and environmental terms. In this paper, we analyze the robustness of different technology portfolios under a wide range of possible future socioeconomic and technological outcomes. We illustrate our point with thirteen, state-of-the-art, global energy-economic development scenarios. These scenarios illustrate possible future pathways of the world energy system. They are long-term scenarios for the $21^{\text {st }}$ century, since a time scale of 100 years or more is characteristic for interactions ${ }^{1}$ between human activities ${ }^{2}$ and climate change.

In our analysis, we compare the following different sets of scenarios:

- Nine non-climate policy scenarios. These scenarios are versions of scenarios (created by the authors) that are part of the recent Special Report on Emissions Scenarios (SRES) by the Intergovernmental Panel on Climate Change (IPCC) (SRES 2000; Nakicenovic (ed.) 2000). We refer to these scenarios as IIASA SRES scenarios.

- Five baseline reference scenarios. This subset of the IIASA SRES scenarios leads to relatively high GHG emissions levels by the end of the $21^{\text {st }}$ century. They are non-sustainable in terms of resource use, equity, environmental impacts, or for other reasons (see Section 2.1.1.).

- Four sustainable development scenarios. This subset of the IIASA SRES scenarios explores possible pathways of sustainable development. In these scenarios, relatively low GHG emissions levels are achieved through combinations of policies not customarily thought of as climate policies at all (see Section 2.1.2.).

- Four carbon dioxide $\left(\mathrm{CO}_{2}\right)$ mitigation scenarios. Using the IIASA SRES scenarios (SRES 2000) as baselines we study cost-optimal strategies and cross-benefits from individual emissions reduction measures, to stabilize atmospheric $\mathrm{CO}_{2}$ concentrations at $550 \mathrm{ppmv}$ (parts per million by volume) by the end of the $21^{\text {st }}$ century (see Section 2.2.). We restrict ourselves to analyzing $\mathrm{CO}_{2}$ mitigation in the global energy sector, since $\mathrm{CO}_{2}$ is the main anthropogenic (i.e., due to human activities) contributor to climate

\footnotetext{
${ }^{1}$ Note that the nature of these interactions is still highly uncertain, and uncertainties in demographic and economic development and technological progress are large.

${ }^{2}$ Human activities, such as energy production and use, result in greenhouse gas (GHG) emissions, changes in the atmospheric concentrations of GHGs, their influence on changes in the radiative balance of the planet, and, hence, climate change.
} 
change. ${ }^{3}$ The portfolio of future response strategies will include an appropriate economic and regulatory framework for consumers and investors, leading edge technologies, and "no regrets" solutions.

\section{Energy-economic development scenarios}

This section presents and compares different groups of energy-economic, global development scenarios for the $21^{\text {st }}$ century (see Table 1). Appendix I briefly summarizes the main characteristics of the modeling framework that was used by the authors to quantify these scenarios (i.e., alternative future pathways) of the global energy system and GHG emissions. The principal models and data sets that were used include the Scenario Generator (SG) (Nakicenovic et al. 1998a,b), the bottom-up energy systems engineering model MESSAGE ${ }^{4}$ (Messner and Strubegger 1995), the top-down macroeconomic model MACRO (Messner and Schrattenholzer 1999), the climate impact model MAGICC ${ }^{5}$ (Wigley and Raper 1997), and several databases, including the CO2DB (Messner and Strubegger 1991).

Non-climate-policy scenarios ${ }^{6}$ (Section 2.1.) describe possible future pathways in the case that no direct climate policies are introduced on a global scale. A subset of these non-climate-policy scenarios, the sustainable development scenarios (Section 2.1.2.), are based on a wide range of non-climate-policies that aim to achieve sustainable development, and are particularly geared toward equity issues. These scenarios often lead to relatively low GHG emissions levels. Another subset of the non-climate-policy scenarios, the baseline reference scenarios (Section 2.1.1.), lead to significant GHG emissions levels. These scenarios are used as baselines to create $\mathrm{CO}_{2}$ mitigation scenarios in Section 2.2., where climate policies lead to a stabilization of atmospheric $\mathrm{CO}_{2}$ concentrations at a level of 550 ppmv.

In the real world the division lines between these categories of future pathways are vague, since there are multiple links and interactions between economic

\footnotetext{
${ }^{3} \mathrm{CO}_{2}$ from past emissions is currently responsible for more than $60 \%$ of the enhanced greenhouse effect that is due to human activities (IPCC 1996). Other important anthropogenic greenhouse gases are, e.g., methane $\left(\mathrm{CH}_{4}\right)$, nitrous oxide $\left(\mathrm{N}_{2} \mathrm{O}\right)$, chlorofluorocarbons (CFCs), tropospheric ozone, and other gases. These anthropogenic emissions have significantly altered the atmospheric composition. Whereas carbon dioxide levels varied by less than $10 \%$ during the 10000 years before industrialization, since 1800 these levels have risen by almost $30 \%$. The ozone precursors nitrogen oxides $\left(\mathrm{NO}_{\mathrm{x}}\right)$, carbon monoxide $(\mathrm{CO})$, and non-methane hydrocarbons or volatile organic compounds (NMVOCs) are not greenhouse gases themselves, but are involved in a complex chain of reactions in the troposphere that lead to the production of ozone, an important greenhouse gas. Trajectories for all these gases are modeled for the scenarios presented in this paper.

${ }^{+}$MESSAGE: Model for Energy Supply Strategy Alternatives and their General Environmental Impact.

${ }^{5}$ MAGICC: Model for the Assessment of Greenhouse-gas Induced Climate Change.

${ }^{6}$ Note that the Evaluation Report of the IPCC (1995) refers to these scenarios as nonintervention scenarios.
} 
Table 1. Overview of scenario drivers and results

\begin{tabular}{|c|c|c|c|c|c|c|c|c|c|c|c|c|c|}
\hline \multirow[b]{2}{*}{ Scenario/Year } & \multirow[t]{2}{*}{$\begin{array}{l}\text { Type of Scenario } \\
\text { (B: Baseline } \\
\text { reference, } \\
\text { M: Mitigation', } \\
\text { S: Sustainable } \\
\text { development) }\end{array}$} & \multicolumn{2}{|c|}{$\begin{array}{c}\text { Population } \\
\text { [billion] }\end{array}$} & \multicolumn{2}{|c|}{$\begin{array}{c}\text { Gross } \\
\text { Domestic } \\
\text { Product } \\
\text { (GDP) } \\
\text { [trillion } \\
(1990) \text { US\$] }\end{array}$} & \multirow[t]{2}{*}{$\begin{array}{c}\text { Equity, } \\
\text { Ratio of } \\
\text { incomes } \\
\text { between DEV } \\
\text { and IND } \\
\text { regions in } 2100 \\
2100\end{array}$} & \multicolumn{2}{|c|}{$\begin{array}{c}\text { Primary } \\
\text { Energy } \\
{[\mathrm{EJ}]}\end{array}$} & \multirow{2}{*}{$\begin{array}{c}\text { Cumulative } \\
\mathrm{CO}_{2} \\
\text { Emissions } \\
{[\mathrm{GtC}]} \\
199(0)-2100 \\
\end{array}$} & \multirow[t]{2}{*}{$\begin{array}{c}\text { Atmospheric } \\
\mathrm{CO}_{2} \\
\text { Concentration } \\
\text { ("S" means } \\
\text { stabilized) } \\
\text { [ppmv] } \\
2100\end{array}$} & \multicolumn{2}{|c|}{$\begin{array}{c}\mathrm{SO}_{2} \\
\text { Emissions } \\
{[\mathrm{MtS}]}\end{array}$} & \multirow[t]{2}{*}{$\begin{array}{c}\text { Global } \\
\text { Temperature } \\
\text { Change } \\
{ }^{8} \text { (relative to } \\
1990)\left[{ }^{\circ} \mathrm{C}\right] \\
2100 \\
\end{array}$} \\
\hline & & 2050 & 2100 & 2050 & 2100 & & 2050 & 2100 & & & 2050 & 2100 & \\
\hline $\mathrm{A} 2$ & $\mathrm{~B}$ & 11.30 & 15.07 & 82 & 243 & 0.24 & 1014 & 1921 & 1662 & 783 & 100 & 66 & 2.7 \\
\hline A2-550 & M & 11.30 & 15.07 & 81 & 236 & 0.23 & 959 & 1571 & 1210 & $\sim 550(\mathrm{~S})$ & 81 & 54 & 2.1 \\
\hline B2 & B & 9.37 & 10.41 & 110 & 235 & 0.33 & 869 & 1357 & 1143 & 603 & 54 & 45 & 2.0 \\
\hline B2-550 & M & 9.37 & 10.41 & 109 & 231 & 0.33 & 881 & 1227 & 971 & $\sim 550(\mathrm{~S})$ & 56 & 38 & 1.8 \\
\hline A1 & B & 8.70 & 7.06 & 187 & 550 & 0.64 & 1422 & 2681 & 1562 & 724 & 55 & 29 & 2.4 \\
\hline A $1-550$ & M & 8.70 & 7.06 & 186 & 547 & 0.63 & 1339 & 2505 & 1095 & $\sim 550(\mathrm{~S})$ & 47 & 19 & 1.9 \\
\hline $\mathrm{A} 1 \mathrm{C}$ & B & 8.70 & 7.06 & 187 & 550 & 0.64 & 1377 & 2325 & 2046 & 950 & 122 & 47 & 3.0 \\
\hline A1C-550 & $\mathrm{M}$ & 8.70 & 7.06 & 185 & 542 & 0.64 & 1269 & 2188 & 1093 & $\sim 550(\mathrm{~S})$ & 71 & 30 & 2.0 \\
\hline $\mathrm{A} 1 \mathrm{G}$ & B & 8.70 & 7.06 & 187 & 550 & 0.64 & 1495 & 2737 & 2092 & 891 & 68 & 38 & 2.8 \\
\hline $\mathrm{A} 1 \mathrm{~T}$ & $S$ & 8.70 & 7.06 & 187 & 550 & 0.64 & 1213 & 2021 & 1122 & 560 & 41 & 17 & 1.9 \\
\hline B1 & $\mathrm{S}$ & 8.70 & 7.06 & 136 & 328 & 0.59 & 837 & 755 & 842 & $486(S)$ & 28 & 9 & 1.7 \\
\hline $\mathrm{B} 1 \mathrm{G}$ & $S$ & 8.70 & 7.06 & 166 & 350 & 0.60 & 911 & 1157 & 902 & 509 & 31 & 13 & 1.8 \\
\hline $\mathrm{B} 1 \mathrm{~T}$ & $\mathrm{~S}$ & 8.70 & 7.06 & 136 & 328 & 0.59 & 819 & 714 & 776 & $464(S)$ & 27 & 8 & 1.6 \\
\hline
\end{tabular}

Compare with 1990 values for population (5.3 billion), GDP (20.9 trillion (1990) US\$), equity ratio between today's developing and industrialized regions ( 0.06$)$, primary energy

(352 EJ), total $\mathrm{CO}_{2}$ emissions $(7.5 \mathrm{GtC}), \mathrm{CO}_{2}$ concentration $(354 \mathrm{ppmv}), \mathrm{SO}_{2}$ emissions $(69.0 \mathrm{MtS})$, and temperature change from 1765 to $1990\left(0.4^{\circ} \mathrm{C}\right.$ assuming a climate sensitivity of $2.5^{\circ} \mathrm{C}$ (Wigley and Raper 1997))

DEV, today's developing countries; IND, today's industrialized countries

7 "M" denotes mitigation scenarios that achieve stabilization of atmospheric $\mathrm{CO}_{2}$ concentration.

${ }^{8}$ Assuming a climate sensitivity of $2.5^{\circ} \mathrm{C}$. 


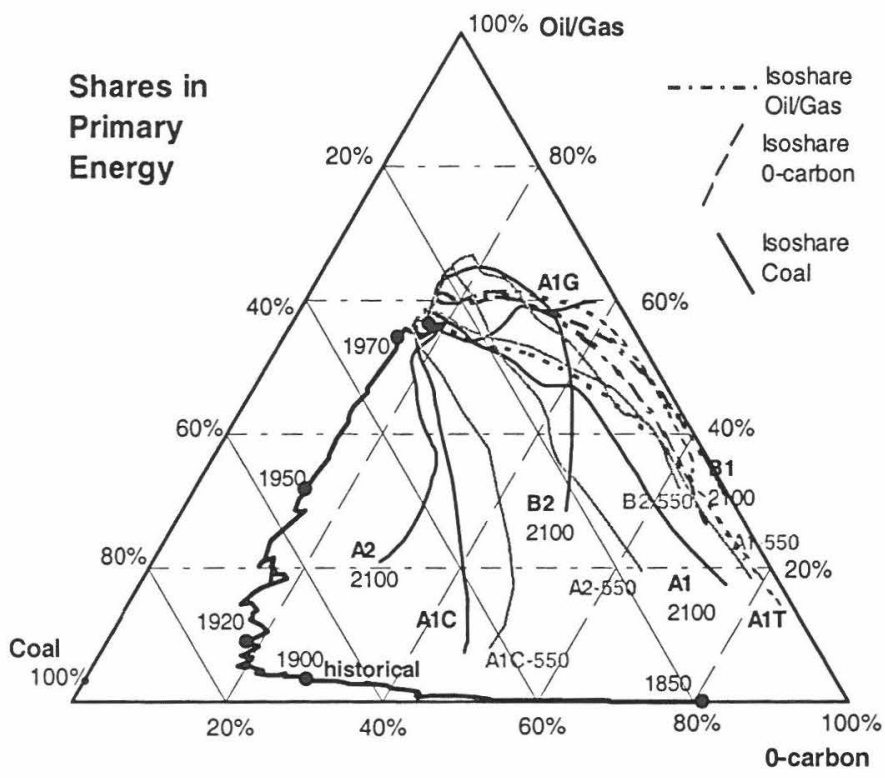

Fig. 1. Global shares in primary energy use, coal, oil/gas, and non-fossil energy, illustrated with an "energy triangle" (in percent). Constant market shares of coal, oil/gas, and nonfossil (zero-carbon) energies are denoted by their respective isoshare lines. Historical data from 1850 to 1990 are based on Nakicenovic et al. 1998a. For the years 1990 to 2100 , alternative trajectories unfold for the five baseline reference scenarios A2, B2, A1, A1G, and $\mathrm{A} 1 \mathrm{C}$, and for the four $550 \mathrm{ppmv} \mathrm{CO}_{2}$ concentration stabilization cases $\mathrm{A} 2-550, \mathrm{~B} 2-550$, A1-550, and A1C-550. However, the four sustainable development scenarios B1, B1G, $\mathrm{B} 1 \mathrm{~T}$, and A1T show similar shifts first toward gas and later toward zero-carbon options

development, ecosystem resilience, poverty, environmental degradation, lifestyles, socioeconomic equity, and different effective policy responses. Clearly, climate policies will have significant consequences for sustainable development on both the global and sub-global scales. And policy responses to sustainable development issues may affect our ability to develop and successfully implement climate policies. Nevertheless, the authors decided to categorize their scenarios into the different groups, because it provides additional insight into the relative impacts of the different measures.

Figure 1 illustrates the changes in the world primary energy structure over time. ${ }^{9}$ The historical changes reflect major technology shifts, from traditional use

\footnotetext{
${ }^{9}$ In this paper, we adopt as primary energy accounting methodology the direct equivalent method for all non-thermal uses of renewables and nuclear. For instance, the primary energy equivalence of electricity generated from solar photovoltaics or nuclear power plants is set equal to their respective gross electricity output and not the heat equivalent of radiation energy from fissile reaction, the solar radiance falling onto a photovoltaic panel and converted to electricity (with efficiencies ranging from $10 \%$ to $15 \%$ ), or the heat that would have to be generated by the burning of fossil fuels to produce the same amount of electricity as generated in a photovoltaic cell or a nuclear reactor (which would be the so-called "substitution" accounting method).
} 
of renewable energy flows to the coal and steam age of the $19^{\text {th }}$ century to the dominance of oil and internal combustion engines in the $20^{\text {th }}$ century. Around 1850 , only about $20 \%$ of world primary energy was provided by coal, with the other $80 \%$ provided by traditional renewable energies (biomass, direct wind and hydropower, and animal and human energy). With the rise of industrialization, coal substituted for traditional renewable energy forms, and by 1920 around three quarters of world primary energy use relied on coal. The second major transition was the replacement of coal by oil and later by gas. By the early 1970s, $56 \%$ of global primary energy use was based on oil and gas. Since then, the global primary energy structure has changed little, and efforts to substitute for oil imports have led to a certain revival of coal and to the introduction of non-fossil alternatives in the OECD countries (e.g., nuclear energy in France). Rapid growth in energy demand and coal use, particularly in Asia, have outweighed energy structural changes in the OECD countries.

\subsection{Non-climate-policy scenarios}

The group of non-climate-policy scenarios presented in this paper are based on a set of narrative descriptions, so-called storylines, that were created by a team of international researchers for the IPCC's Special Report on Emissions (SRES 2000; Nakicenovic (ed.) 2000). ${ }^{10}$

Clearly, certain combinations of scenario driving forces will be more likely than others, since many interrelationships exist between these driving forces. However, because of the complexity of these interrelationships one is left with a wide (though not arbitrary) range of consistent combinations of driving forces, based on different assumptions of socioeconomic development, technological progress, and political change. These result in widely differing world energy systems (Fig. 1), which are all cost-optimal strategies under the given assumptions, and lead to a wide range of emissions levels (see, e.g., Table 1, Figs. 2, 3, and 4).

We start with a brief characterization of the four groups of non-climate-policy scenarios.

- A2: The A2 scenario foresees future development toward a very heterogeneous world, characterized by high population growth in the developing regions, selfreliance in terms of resources, and less emphasis on economic, social, and cultural interactions between world regions. Eventually, the world "consolidates" into a series of economic trade blocks. Compared to the other scenarios in this paper, A2 is characterized by relatively slow capital stock turnover, slower technological change, and a more slowly narrowing income gap between today's industrialized and developing countries.

\footnotetext{
${ }^{10}$ In addition to the scenario quantifications created with the IIASA modeling framework that are described in this paper, the reproducibility of these scenarios was confirmed with emulation runs created using five other models (SRES 2000; Nakicenovic (ed.) 2000).
} 


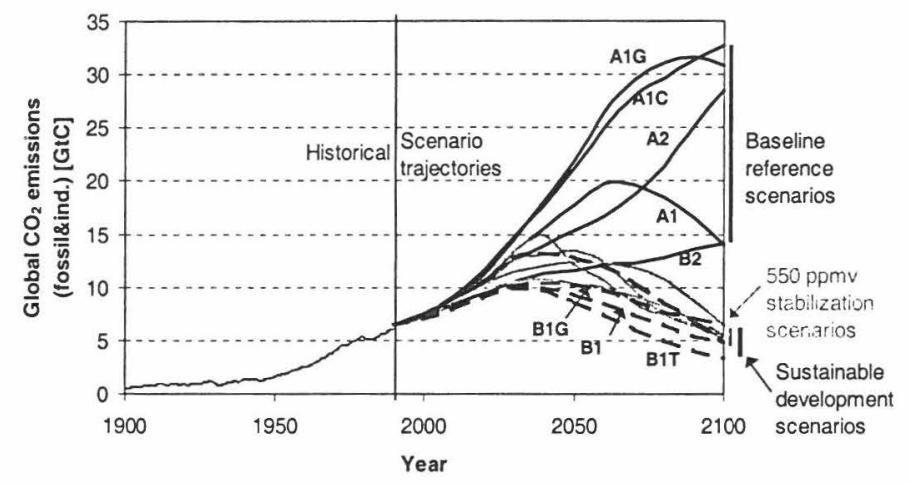

Fig. 2. Global $\mathrm{CO}_{2}$ emissions from fossil fuel combustion and cement production. Historical data from 1850 to 1990 from Marland et al. (1999). Three groups of future development scenarios for 1990 to 2100: (i) Baseline reference scenarios (ii) Sustainable development scenarios (iii) $\mathrm{CO}_{2}$ mitigation scenarios that stabilize at $550 \mathrm{ppmv}$ atmospheric $\mathrm{CO}_{2}$ concentration

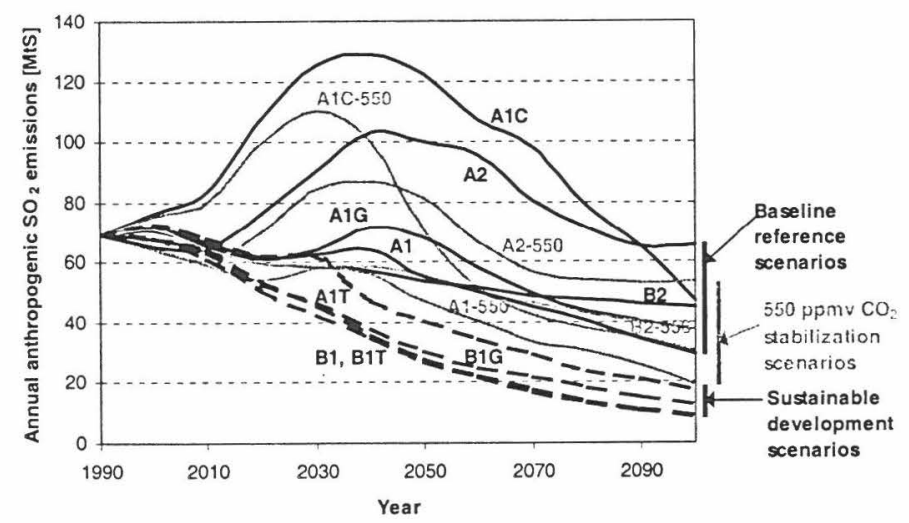

Fig. 3. Global anthropogenic sulphur dioxide emissions in MtS

- B2: The B2 world is one of increased concern for environmental and social sustainability compared to the A2 world. It is a heterogeneous world with more diverse technological change. International institutions decline in importance, with a shift toward local and regional decision-making structures and institutions. Human welfare, equality, and environmental protection all have high priority, and they are addressed through community-based, social solutions in addition to technical solutions, albeit implementation rates vary across regions.

- A1 (A1, A1C, A1G, and A1T): The A1 world describes a future world of very rapid economic growth and low population growth, in which regional average 


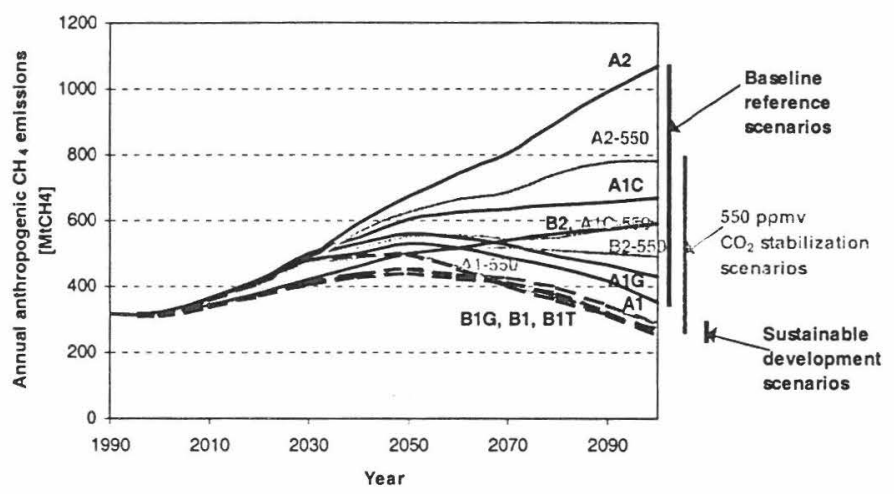

Fig. 4. Global anthropogenic methane emissions in $\mathrm{MtCH} 4$

incomes per capita converge to the extent that the current distinctions between "poor" and "rich" countries eventually dissolve. The main dynamics is based on a strong commitment to market-based solutions. The world is characterized by a strong commitment to education, high rates of investment, and increased international mobility of people, ideas, and technology, accelerated by advances in communication technologies. Due to the particularly large uncertainties in future technological progress in this case, four different cases are analyzed according to different resource and technology development assumptions:

- A1C: "Clean coal" technologies that are generally environmentally friendly with the exception of GHG emissions;

- A1G: "Oil and gas"-rich future, with a swift transition from conventional resources to abundant unconventional resources including methane clathrates;

- A1T: "Post-fossil" future, with rapid development of solar and advanced nuclear technologies ${ }^{11}$ on the supply side, and mini-turbines and fuel cells used in energy end-use applications;

- A1: "Balanced" progress across all resources and technologies from energy supply to end-use.

- B1 (B1, B1G, B1T): The B1 world describes a future world that chooses collectively and effectively to pursue service-oriented economic prosperity while taking into account equity and environmental concerns without policies

\footnotetext{
${ }^{11}$ Advanced nuclear power plants are defined as technologies that produce energy with higher efficiency and increased safety compared to today's nuclear standards. Their technological design is not pre-specified in the model. Advanced nuclear technologies should be interpreted as a technology cluster (consisting of various different designs) rather than a single individual technology. The cluster might include e.g., efficient high temperature reactors (that produce hydrogen), new fast breeder reactors with modified designs, but also other imaginable options for nuclear fission.
} 
directed at mitigating climate change. It is a rapidly converging world, characterized by "dematerialization" and the introduction of clean technologies. The emphasis is on global solutions for environmental and social sustainability, including concerted efforts for rapid technology development, dematerialization of the economy, and improving equity. Technological change plays an important role.

- B1G: "Gas and non-fossil future";

- B1T: Particularly rapid shift to non-fossil and decentralized technologies;

- B1: "Balanced" progress across all resources and technologies.

Altogether, the scenarios illustrate the large uncertainties of the scenario baselines. They also illustrate the fact that similar GHG emissions levels may be reached with very different combinations of input assumptions.

\subsubsection{Baseline reference scenarios}

Among the set of nine non-climate-policy scenarios, five scenarios (A2, B2, A1, A1C, A1G) lead to relatively high levels of GHG emissions and/or high levels of acidification (Table 1, Figs. 2, 3, 4). These scenarios are described here and are used in Section 2.2. as baseline scenarios to introduce climate policies.

A2 baseline scenario The A2 world represents a differentiated world, which "consolidates" into a series of economic regions. Economic growth is uneven and the income gap between poor and rich regions does not narrow as much as in the other scenarios (Table 1). Global average per capita income in A2 is low relative to the other baselines outlined in this paper, and gross world product (GWP) reaches about US\$243 trillion. International disparities in productivity, and hence income per capita, are largely maintained or increased in absolute terms. Fertility rates decline relatively slowly, which leads to a steadily increasing world population reaching 15 billion by 2100 . A combination of slow technological progress (Table 2), more limited environmental concerns, and low land availability because of high population growth means that the energy needs of the A2

Table 2. Technology improvements in the scenarios

\begin{tabular}{lllll}
\hline & \multicolumn{4}{c}{ Technology Improvements } \\
\cline { 2 - 5 } & \multicolumn{1}{c}{ Coal } & \multicolumn{1}{c}{ Oil } & \multicolumn{1}{c}{ Gas } & Non-fossil \\
\hline A2 & Average & Low & Low & Low-Average \\
B2 & Low & Average & Average-High & Average \\
A1 & High & High & High & High \\
A1G & Low & Very High & Very High & Median \\
A1C & High & Low & Low & Low \\
A1T & Low & High & High & Very High \\
B1 & Low-Average & Average-High & High & High \\
B1G & Low-Average & Average-High & High & High \\
B1T & Low-Average & High & High & Very High \\
\hline
\end{tabular}

The categorization is made relative to the other scenarios, not relative to technologies running on different fuels. For a detailed report on assumed technology costs in the scenarios, see SRES (2000) 
world are satisfied primarily by fossil (mostly coal) and nuclear energy (Fig. 1). However, in some cases regional energy shortages force investments into renewable alternatives, such as solar and biomass. Regions with abundant energy and mineral resources evolve to more resource-intensive economies, while those poor in resources place a very high priority on minimizing import dependence through technological innovation to improve resource efficiency and make use of substitute inputs. The fuel mix in different regions is determined primarily by the resource availability (limited to conventional reserves and resources). Highincome but resource-poor regions shift toward advanced post-fossil technologies, while low-income resource-rich regions generally rely on traditional fossil technologies. The A2 world is characterized by relatively slow end-use and supplyside energy efficiency improvements and slow convergence between regions. All this leads to steadily increasing levels of GHG emissions (Figs. 2, 4), with $\mathrm{CO}_{2}$ emissions approaching $28 \mathrm{GtC}$ in 2100.

$B 2$ baseline scenario $^{12}$ In the $\mathrm{B} 2$ world, gross world product grows from US $\$ 20$ trillion in 1990 to US $\$ 235$ trillion in 2100 (Table 1 ) ${ }^{13}$ This corresponds to a longterm average growth rate of $2.2 \%$ from 1990 to 2100 . Most of this growth takes place in today's developing countries, but over the long term economic growth rates in these regions also decline as labor productivity levels approach those of the leading countries. The B2 scenario uses the UN median 1998 population projection (UN 1998), that describes a continuation of historical trends, including recent faster-than-expected fertility declines, toward a completion of the demographic transition within the next century. Global population increases to 10.4 billion by $2100 .{ }^{14}$ Global primary energy needs increase by almost a factor of four to $1360 \mathrm{EJ}$ in 2100 . Most of this increase takes place in today's developing regions. The aggregate global rate at which final energy intensity declines is about one percent per year through 2100. Cost improvement rates for most technologies are moderate, however, they are largest for non-sulfur-emitting technologies due to local and regional pollution control (Fig. 3). These include in particular wind and solar photovoltaics, but also gas combined-cycle, integrated gasification combined-cycle (IGCC), solar thermal power plants, and advanced nuclear power plants ${ }^{15}$ (see also Fig. 1). Coal costs increase in regions with large shares of

\footnotetext{
${ }^{12}$ See Riahi and Roehrl (2000) for more details.

${ }^{13}$ When not mentioned explicitly otherwise, gross world product (GWP), gross domestic product (GDP), and related parameters are reported at market exchange rates, in 1990 US\$.

${ }^{14}$ Although, in the long term, global fertility levels gradually approach replacement levels, the path and pace of fertility change vary greatly among the regions.

${ }_{15}$ Advanced nuclear power plants are defined as technologies that produce energy with higher efficiency and increased safety compared to today's nuclear standards. Their technological design is not pre-specified in the model. Advanced nuclear technologies should be interpreted as a technology cluster (consisting of various different designs) rather than a single individual technology. The cluster might include e.g., efficient high temperature reactors (that produce hydrogen), new fast breeder reactors with modified designs, but also other imaginable options for nuclear fission.
} 
deep mined coal and high population densities, although coal costs are assumed to remain relatively low in regions with abundant surface coal reserves such as North America and Australia. The overall energy system efficiency, from primary to useful energy, ${ }^{16}$ increases substantially, from $36 \%$ in 1990 to $53 \%$ in 2100. Altogether, the B2 scenario exhibits linearly increasing global GHG emissions (Figs. 2, 4), with $\mathrm{CO}_{2}$ emissions reaching $14 \mathrm{GtC}$ by 2100.

Al baseline scenarios $^{17}$ The A1 scenarios describe cases of rapid economic development, which implies a replication of the postwar growth experience of Japan and South Korea or the recent economic development of China on a global scale, making current distinctions between "poor" and "rich" regions largely obsolete. Free trade, continued innovation, and a stable political and social climate enable developing regions to access knowledge, technology, and capital. The global economy is projected to expand rapidly at an average annual rate of $3 \%$ to $2100^{18}$ (Table 1), which translates into a global economic output of US $\$ 550$ trillion by 2100. As a byproduct of rapid economic development and a fast demographic transition, income inequities between today's industrialized and developing countries almost completely vanish in the course of the $21^{\text {st }}$ century (Table 1 ). We use the low population projection reported by Lutz et al. $(1996,1997)$ that combines low fertility with low mortality and central migration rate assumptions. After peaking at 8.7 billion in the middle of the $21^{\text {st }}$ century, world population declines to 7.1 billion in the year 2100 (see Table 1). The A1 world is characterized by relatively high energy demand (Table 1), compared to the more "green" B1 scenarios (see Section 2.1.2.), as low energy prices provide little incentive to improve end-use-energy efficiencies, and high income levels encourage comfortable and convenient (often energy-intensive) lifestyles. Figure 1 shows possible future evolutions of the global primary energy structure from 1990-2100 according to different technology dynamics and resource availability assumptions. We assume technological change in energy conversion and supply technologies to be strongly interrelated. ${ }^{19}$

Coal-intensive $A 1 C$. The high-growth, coal-intensive scenario A1C illustrates the long-term implications of quickly "running out of conventional oil and gas,"

\footnotetext{
${ }^{16}$ Useful energy is defined as the energy, which is actually consumed by the end-user, e.g., radiation from light bulbs, or heat from boilers or heat pumps. Thus, technologies at the useful energy level (light bulbs, automobiles, boilers, etc.) have final energy as an input and useful energy as an output.

${ }_{17}$ See Roehrl and Riahi (2000) for more details.

${ }^{18}$ This rate is roughly in line with long-term historical experience over the last 100 years (Maddison 1993).

${ }_{19}$ Resource availability in each of the scenarios therefore depends on the alternative investment strategies into exploration, production, and conversion technologies. As outlined in Section 2.2 .5 on the MESSAGE model, time profiles of costs of energy conversion and supply technologies are direct input assumptions. Reserves/resources are split into different cost categories following Rogner (1997). In other words, we chose consistent resource and technology assumptions; they are not outputs of the model.
} 
combined with slow progress in developing alternatives, except for progress in coal-related technologies (Table 2). It assumes relatively high-cost improvements in new and clean coal technologies such as coal high-temperature fuel cells ${ }^{20}$ integrated coal gasification combined-cycle power plants (IGCC) and coal liquefaction. Only modest assumptions are made for all other technologies, except for nuclear technologies. In terms of resource assumptions, A1C is restricted mainly to the availability of currently assessed quantities of conventional oil and gas, which results in very high cumulative coal use. In 2100 , the main primary energy carrier is coal, which has a share of $47 \%$, but all of that coal is converted to highquality fuels demanded by the affluent consumers of the 21st century. Demand for coal is so large that some world regions run out of coal, whereas large coal occurrences remain available in the former Soviet Union, North America, and to some extent China. Therefore, a large-scale global methanol trade unfolds. In 2100 , the transport sector, for example, depends on methanol produced from coal for $64 \%$ of its energy use. Some coal-poor regions try to rely increasingly on nuclear technologies to ease their import dependence. Altogether, the A1C scenario is the scenario with the highest GHG emissions levels of all scenarios in this paper, with $\mathrm{CO}_{2}$ emissions approaching $33 \mathrm{GtC}$ by 2100 (Fig. 2).

Oil-and gas-intensive A1G. The high-growth oil and gas-intensive scenario A1G explores a high-growth future with rapid technological progress for extraction and conversion technologies (Table 2) of oil and gas (conventional and unconventional). In addition to the improvement and extension of present oil and gas grids and transportation/distribution infrastructure, new natural gas pipelines from Siberia, the Caspian, and the Middle East to China, Korea, Japan, and South Asia (India) are introduced in the scenario after 2010/2020. It is assumed that the extraction of natural gas hydrates and of unconventional oil like oil shales or natural bitumen (tar sands) becomes economically feasible on a large scale, beyond current niche market applications. This leads to a world dominated first by oil and later by gas as primary energy fuels. There is large-scale gas and oil trade, mainly from the former Soviet Union and the Middle East. The main primary energy carriers in 2100 are natural gas $(45 \%)$, oil (14\%), nuclear $(12 \%)$, and renewables (25\%) (Fig. 1). $\mathrm{CO}_{2}$ emissions approach a high level of about 31 GtC by 2100 (Fig. 2).

"Balanced technology" A1. The high-growth, "balanced technology" A1 baseline scenario explores "balanced" progress across all resources and technologies from energy supply to end use. Investment costs for electricity generation with solar photovoltaic technology decrease by a factor of more than 10 , those for fuel cells, hydrogen, and wind technologies by a factor of 2 to 5 , and those of advanced nuclear technologies by a factor of 1 to 3 . Liquid fuels from coal or unconventional oil/gas resources become available at less than $\$ 30$ per barrel, with costs

${ }^{20}$ With high efficiencies. 
falling further by about $1 \%$ per year with exploitation of learning curve effects. Non-fossil electricity (photovoltaics, advanced nuclear) becomes available at costs of less than $10 \mathrm{mills} / \mathrm{kWh}(0.01 \$ / \mathrm{kWh})$, and continue to improve further (perhaps as low as $1 \mathrm{mills} / \mathrm{kWh}$ ). Energy resources are taken to be plentiful by assuming large reserves of unconventional oil and gas and high levels of improvement in the efficiency of energy exploitation technologies, energy conversion technologies, and transport technologies. This results in initially large hydrocarbon use which is later increasingly substituted by zero-carbon options. In the A1 scenario, $\mathrm{CO}_{2}$ emissions peak at $20 \mathrm{GtC}$ by 2060 , and decline thereafter to $14 \mathrm{GtC}$ in 2100 (Fig. 2).

\subsubsection{Sustainable development scenarios}

In this section we consider futures that require radical policy and behavioral changes to achieve a transition to a sustainable development path without making any explicit assumptions about reduction of GHG emissions. ${ }^{21}$ These scenarios describe relatively low emissions futures (Table 1, Figs. 2, 3, 4). To the extent that they do not include explicit policies and measures directed at mitigating climate change, they are usually considered to be non-climate-policy scenarios. However, there is a certain area of ambiguity as to what constitutes policies that are solely directed at climate change, in contrast to those that are directed at achieving sustainable development in general. Clearly, there are many linkages between environmental issues, sustainability, economic issues, development, social issues, and equity. Therefore, it seems valuable to compare and analyze sustainable development policies and climate policies.

In our set of scenarios, we have identified four scenarios as sustainable development scenarios that do not incorporate explicit climate policies, but successfully achieve environmentally and socially compatible targets. The B1 scenarios (B1, B1G, and B1T) achieve this through a successful combination of international collaboration, technological development, energy savings, and environmentally oriented world economics, whereas also a high-energy-demand scenario (A1T) may eventually lead to a sustainable development path provided technological progress is extremely successful, and leads to the rapid deployment of clean and efficient technologies. The four sustainable development scenarios all show low GHG emissions levels (Figs. 2, 4), as well as low levels of acidification (Fig. 3). They are based on moderate use of resources, and achieve very high levels of equity.

$B 1$ sustainable development scenarios $(B 1, B 1 G, B 1 T)$ B1 describes a future world that chooses collectively and effectively to pursue service-oriented economic prosperity while taking into account equity and environmental concerns without policies directed at mitigating climate change. A more equitable income

\footnotetext{
${ }^{21}$ One of the first scenarios in the literature that focussed on the achievement of a sustainable development path in the world was formulated by Greenpeace (Lazarus et al. 1993).
} 
distribution (Table 1), both within and between regions, is increasingly seen as a precondition for sustainable development. ${ }^{22}$ Global GDP ${ }^{23}$ reaches US\$330 trillion in 2100 , which corresponds to an average annual growth rate of $2.5 \%{ }^{24}$ The world population projections used in $\mathrm{B} 1$ are identical to those in the A1 scenarios (see above). B1 is characterized by a strong commitment toward sustainable development initiatives and sustainable resources use, and a continuation of the present trends of globalization and liberalization. The industrialized countries support sustainable development in the poor regions, including technology transfer. Subsidies for traditional energy technologies and fuels are abolished, and capital markets increasingly respond negatively to adverse environmental incidents, which leads to careful land management and the deployment of "clean" energy technologies (Table 2, Fig. 3). These technologies are developed for economic or strategic reasons (rather than for a climate-policy target), and for niche markets as part of autonomous economic dynamics. The particular institutional developments in the B1 world favor decentralized energy supply. The transport, residential/commercial, and industrial sectors rely increasingly on fuel cell-based electricity generation. The B1G scenario explores, in particular, natural gas-based infrastructures as a transition to hydrogen as the dominant fuel, whereas B1T illustrates the very optimistic case in which the world energy system leapfrogs directly to a hydrogen-based economy. Resulting emissions levels are among the lowest of all the scenarios considered here (Figs. 2, 3, 4). In particular, $\mathrm{CO}_{2}$ emissions in 2100 range from $3 \mathrm{GtC}$ in $\mathrm{B} 1 \mathrm{~T}$ to $6 \mathrm{GtC}$ in $\mathrm{B} 1 \mathrm{G}$.

A1T, a high growth, post-fossil sustainable development scenario A1T, the "postfossil" version of the 550 trillion US\$ A1 scenarios (described in Section 2.1.1) explores a case of very rapid technological change for non-fossil alternatives, and increased final to end-use efficiency (Tables 1,2). A large contrast to the B1 scenarios is the very high level of energy services. However, potential adverse environmental impacts of such an energy-intensive world economy are increasingly counterbalanced by a rapid development of solar and advanced nuclear technologies on the supply side, and mini-turbines and fuel cells used in energy end-use applications. Furthermore, A1T would imply the large-scale installation of new, inherently safe and cheap nuclear technologies (e.g., future hightemperature reactors) and new renewable technologies. A1T assumes medium levels of resource availability for oil and gas. However, because of fast technological progress in post-fossil alternatives, oil, gas, and coal extraction levels remain relatively small. In 2100 , the main primary energy carriers are renewables and nuclear 1722 EJ (86\%) and natural gas at 196 EJ (10\%). The shift toward carbon-free and also decentralized technologies is nearly complete in all world regions by 2100 (Fig. 1). However, it is not straightforward to determine the

\footnotetext{
22 Also, the rapid expansion of telecommunications and information technology gives lessdeveloped regions important leapfrogging opportunities.

23 In B1, concepts of "green" GDP gain increasing importance.

${ }^{24}$ This rate is slightly less than the long-term historical average.
} 
magnitude of targeted $R \& D$ investments that would be needed worldwide to make such a technology-optimistic scenario feasible. Resulting $\mathrm{CO}_{2}$ emissions peak at $13 \mathrm{GtC}$ in 2050 , and decline thereafter to about $5 \mathrm{GtC}$ in 2100.

The likelihood of sustainable development scenarios, as outlined in this section, depends greatly on how counteracting forces will evolve in the future (de Vries et al. 2000). The question arises, as to whether the trends toward globalization and worldwide co-operation can be accelerated to the extent quantified in the B1 and A1T scenarios. Some believe that the drive toward cultural identity and diversity might be very strong and directed against globalization and liberalization (see, e.g., Huntington 1997). In any case, enormous efforts and intercultural understanding will be needed, all over the world. Others believe that the reality of a "global village" may remain the privilege of a small elite, which will become increasingly indifferent to local concerns (Thurow 1996). Free-rider behavior of countries, and an increasing unwillingness of people in the industrialized countries to sacrifice present consumption-oriented lifestyles, or to adopt to new technologies, may be other potential barriers towards a realization of the sustainable development scenarios as outlined in this section.

To sum up, it may be possible to very significantly reduce GHG emissions through a combination of policies not customarily thought of as climate policies at all.

Note also that, in the our interpretation, among the $\mathrm{CO}_{2}$ stabilization cases (that include direct climate policies) described in Section 2.2. below, B2-550 and A1-550 (but not A1C-550 or A2-550) might be named "sustainable development scenarios." Therefore, sustainable development scenarios may include both climate policy and non-climate-policy-scenarios.

\section{$2.2 \mathrm{CO}_{2}$ mitigation scenarios}

In the preceding section, a set of non-climate-policy scenarios was analyzed that result in a wide range of $\mathrm{CO}_{2}$ emissions levels. Some of these scenarios (A2, B2, $\mathrm{A} 1 \mathrm{C}, \mathrm{A} 1 \mathrm{G}, \mathrm{A} 1$ ) show rising $\mathrm{CO}_{2}$ emissions profiles, where carbon emissions increase to more than double today's emissions level by 2100 (Fig. 2). Since the largest anthropogenic contributor to global warming is $\mathrm{CO}_{2}$ (IPCC 1996), these scenarios might lead to significant climate change impacts (Section 4) in the $21^{\text {st }}$ century. Therefore, this section analyzes cost-optimal strategies and crossbenefits from individual emissions reduction measures, illustrated with alternative $\mathrm{CO}_{2}$ mitigation scenarios. ${ }^{25}$

Here we specifically present $\mathrm{CO}_{2}$ mitigation scenarios in which emissions trajectories lead to a stabilization of atmospheric $\mathrm{CO}_{2}$ concentrations. ${ }^{26}$ Since large

\footnotetext{
${ }^{25}$ GHG mitigation scenarios are usually defined as a description and a quantified projection of how GHG emissions can be reduced with respect to some baseline scenario to meet specific targets.

${ }^{26}$ Mitigation scenarios are usually classified into concentration stabilization scenarios, emission stabilization scenarios, and other types of mitigation scenarios.
} 
scientific uncertainties remain about expected future emissions levels and technological pathways (Section 2.1), we have studied a multitude of stabilization cases based on a set of diverging baseline scenarios. Using the non-climate-policy scenarios with high emissions profiles, A2, B2, A1, and $\mathrm{A} 1 \mathrm{C},{ }^{27}$ as baseline scenarios, the $\mathrm{CO}_{2}$ stabilization scenarios A2-550, B2-550, A1-550, and A1C-550 have been developed. For these stabilization cases we considered the same menu of technologies and the same assumptions of resource availability as for the baseline scenarios. To achieve stabilization of atmospheric concentrations, global linearized $\mathrm{CO}_{2}$ concentration limits for the given future target year 2100 were introduced into the MESSAGE model via weighted sums of cumulative $\mathrm{CO}_{2}$ emissions from 1990 to $2100 .^{28}$ The climate-policy scenarios A2-550, B2-550, A1550 , and $\mathrm{A} 1 \mathrm{C}-550$ are constrained to stabilize atmospheric $\mathrm{CO}_{2}$ concentration at approximately $550 \mathrm{ppmv}^{29}$ in 2100 . The resulting $\mathrm{CO}_{2}$ emissions are illustrated in Fig. 2. Note also that the sustainable development scenarios of Section 2.1.2. show similar emissions trajectories to the four $\mathrm{CO}_{2}$ mitigation/stabilization cases described here. Both scenario groups, the sustainable scenarios and the stabilization scenarios, cluster around the range of 4 to $7 \mathrm{GtC}$ in 2100 (see Fig. 2).

The four stabilization scenarios A1-550, A1C-550, A2-550, and B2-550 are based on iterated runs of MESSAGE and MACRO. The macroeconomic model MACRO is important, because the carbon constraint increases energy prices, which reduces energy demand, other things being equal. MACRO calculates this macroeconomic effect. Because both MESSAGE and MACRO are global optimization models, the model results are cost-optimal actions to meet the given carbon constraint. The results assume full spatial and temporal flexibility, including the free movement of investments. However, cost-optimal $\mathrm{CO}_{2}$ emissions reduction possibilities do not necessarily occur in regions that give high priority to such reductions and that have the money to pay for them. Indeed, currently the cheapest $\mathrm{CO}_{2}$ reduction opportunities appear to be in developing

\footnotetext{
${ }^{27}$ Also the gas-intensive A1G scenario illustrates a high emissions future ( $31 \mathrm{GtC}$ in 2100 ). However, we do not describe a $\mathrm{CO}_{2}$ mitigation case for the $\mathrm{A} 1 \mathrm{G}$ baseline in this paper, since indicative results (Roehrl and Riahi 2000) show that major findings in this case do not differ very much from the coal-intensive $\mathrm{A} 1 \mathrm{C}$ case, and since we otherwise overemphasize the conclusions from high-growth baselines in the samples used in the robustness analysis of Section 4.

${ }^{28}$ Emissions from specific years are translated into concentrations in the target year using trajectories of weighting factors. These weighting factors represent the contribution of the emissions in the year when they take place to the concentration in the year for which the limit is set, i.e., the year 2100 in the calculations reported here. In other words, the linearized concentration constraints approximate the effects of the carbon cycle (using a time profile of when a unit of $\mathrm{CO}_{2}$ emitted into the atmosphere is absorbed by a variety of sinks, most notably the oceans).

${ }^{29} 550 \mathrm{ppmv}$ is simply the middle of five stabilization levels analyzed by Wigley et al. (1996). We choose it here for illustrative purposes only and do not propose to argue that it would necessarily satisfy the UNFCCC objective of preventing "dangerous anthropogenic interference with the climate system."
} 
countries, while it is the industrialized countries that currently appear most willing to pay for them. The stabilization scenarios can thus be seen as possible answers to the question, "Which are the best strategies to achieve stabilization if the world generally consistent with the (respective) baseline was able to successfully coordinate and cooperate on efforts to limit potential global warming?"

In Section 2.2.1, we first focus on the most promising strategies to mitigate carbon emissions. Section 2.2.2. then summarizes the economic impact of applying carbon reduction measures.

\subsubsection{Strategies to mitigate carbon emissions}

In general, strategies to mitigate $\mathrm{CO}_{2}$ emissions may be based on technological change, economic incentives, and institutional frameworks. They range from using the carbon sequestering potential of afforestation to demand-side or supply-side oriented measures in the energy sector, and even so-called geo- and cosmo-engineering (Nakicenovic et al. 1993). For simplicity, here we confine our discussion to $\mathrm{CO}_{2}$ abatement measures in the energy sector.

In the energy sector, there are many types of technological strategies for stabilizing and eventually reducing energy-related emissions, including, e.g., the incremental replacement of technologies to improve energy efficiency. ${ }^{30}$ Another number of strategies are often referred to as "add-on" environmental strategies. They include, for example, $\mathrm{CO}_{2}$ removal by scrubbing and $\mathrm{CO}_{2}$ recovery from flue gases. After recovery of $\mathrm{CO}_{2}$ from the energy system it has to be disposed of, stored, or otherwise used. For example in what is called enhanced oil recovery, $\mathrm{CO}_{2}$ is injected in oil fields (originally to improve the oil recovery rate). $\mathrm{CO}_{2}$ may also be stored in depleted natural gas and other underground reservoirs, and eventually also in the deep ocean (Marchetti 1989).

To determine the potential for and costs of the various mitigation strategies, the choice of the baseline scenario is critically important (Roehrl and Riahi 2000). A review of the general mitigation scenario literature suggests that the characteristics of the baseline scenario driving forces interact in complex ways with GHG emissions in the baseline, and with the potential for fuel switching or energy efficiency (SRES 2000). In our analysis we use four baseline scenarios to explore the most promising reduction measures to stabilize atmospheric carbon concentrations. Based on the four baseline scenarios A1, A1C, A2, and B2 (see Section 2.1.1.), we have developed a set of four stabilization cases A1-550, A1C$550, \mathrm{~A} 2-550$, and B2-550, that stabilize $\mathrm{CO}_{2}$ concentrations at the level of about 550 ppmv by 2100 .

The resulting $\mathrm{CO}_{2}$ emissions trajectories of the four mitigation scenarios are shown in Fig. 5 (see also Fig. 2). They are characterized by a peak of about 10 (B2) to 15 (A1C) GtC around the middle of the $21^{\text {st }}$ century. Subsequently, emissions decline to slightly less than the 1990 emissions level (6 GtC) by 2100

\footnotetext{
${ }^{30}$ For example, energy end-use is the least efficient part of the current energy systems and therefore has the highest potential for efficiency improvements (Nakicenovic et al. 1998a).
} 
$\mathrm{CO}_{2}$ reductions by source from $\mathrm{A} 1$ to $\mathrm{A} 1-550$

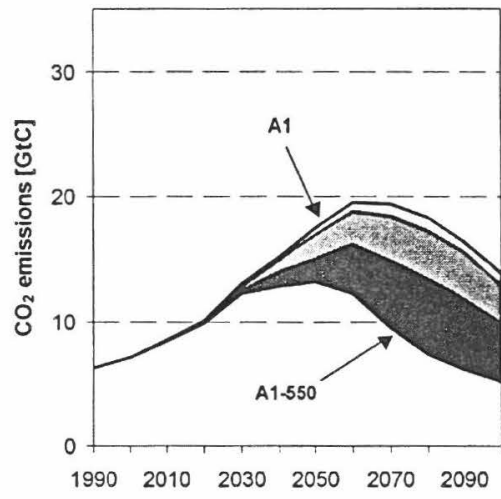

$\mathrm{CO}_{2}$ reductions by source from $\mathrm{B} 2$ to $\mathrm{B} 2-550$

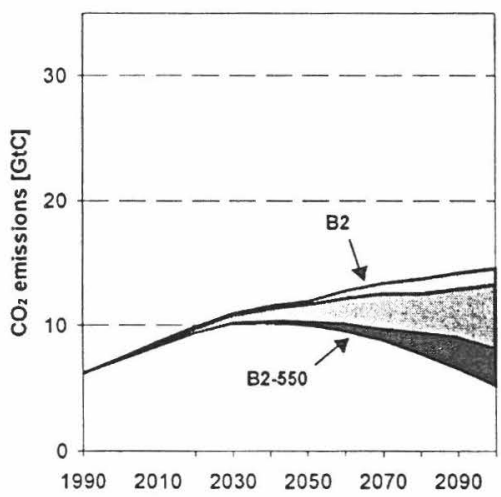

$\mathrm{CO}_{2}$ reductions by source from $\mathrm{A} 1 \mathrm{C}$ to $\mathrm{A} 1 \mathrm{C}-550$

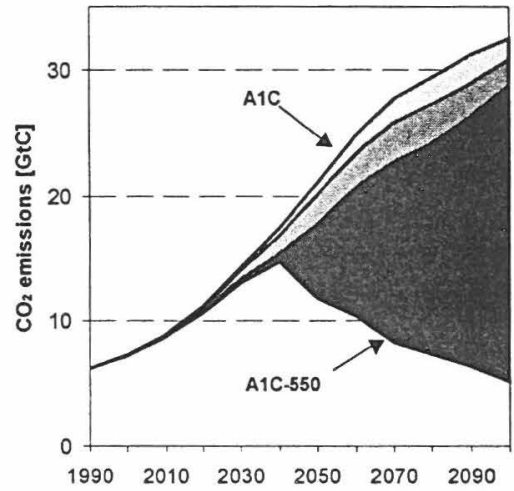

a Demand reduction

Fuel switching

(mainly shifts away from coal)

CO2 scrubbing and removal

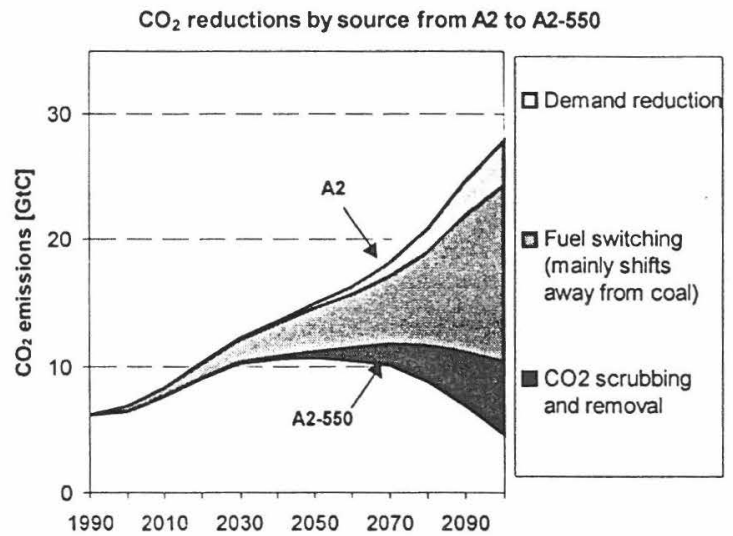

Fig. 5. $\mathrm{CO}_{2}$ emissions in the baseline scenarios (A1, A1C, A2, and $\mathrm{B} 2$ ) and in the $\mathrm{CO}_{2}$ mitigation scenarios (A1-550, A1C-550, A2-550, and B2-550). The shaded areas depict the three main sources of $\mathrm{CO}_{2}$ reductions in the global energy systems of the mitigation scenarios, compared to the respective baseline scenarios. Structural shifts away from coal, carbon scrubbing/removal, and enhanced energy conservation account for the bulk of the reductions in all mitigation cases. The contribution of the three mitigation measures to total carbon reduction differs widely, depending on the baseline scenario that was explored

in all the $\mathrm{CO}_{2}$ mitigation scenarios. These emissions profiles are close to other emissions trajectories for $550 \mathrm{ppmv}$ stabilization cases found in the literature (Wigley et al. 1996; Roehrl and Riahi 2000). The similarity of the emissions pathways indicates limited flexibility of the timing and pace of emissions trajectories, to achieve $\mathrm{CO}_{2}$ concentration stabilization at $550 \mathrm{ppmv}$ with the least effort. Furthermore, through 2020, emissions levels in the stabilization runs and their baseline counterparts are similar. Only after 2020, do emissions reductions become more pronounced. This is partly because power plants have lifetimes on the order of 30-40 years, which makes for slow turnover in the energy capital stock, and partly because of the temporal flexibility built into the concentration constraint. MESSAGE is free to choose when to reduce carbon emissions, and later 
reductions coinciding with turnover in capital plant are usually cheaper, because of both technological progress and discounting. ${ }^{31}$

Costs and efforts to reduce carbon emissions to meet a specific concentration stabilization target are not only predetermined by the baseline scenario's $\mathrm{CO}_{2}$ emissions. Clearly, to meet a distinct $\mathrm{CO}_{2}$ concentration stabilization level, more $\mathrm{CO}_{2}$ has to be reduced in baseline scenarios with relatively high emissions. For example, for the $\mathrm{A} 2$ (28 GtC in 2100) and the $\mathrm{A} 1 \mathrm{C}(32 \mathrm{GtC}$ in 2100$)$ baseline scenarios, the necessary $\mathrm{CO}_{2}$ reductions in 2100 (Fig. 5) are around three times as large as for the $\mathrm{A} 1$ or $\mathrm{B} 2$ baseline scenarios (with emissions of $14 \mathrm{GtC}$ in 2100), in order to achieve the same $550 \mathrm{ppmv}$ stabilization target. However, the flexibility for (or costs of) reducing $\mathrm{CO}_{2}$ emissions even differ significantly for baseline scenarios with similar emissions levels. They are a function of baseline scenario assumptions, such as technological development (cost reductions over time), resource availability, and socioeconomic development.

Baseline assumptions of technological development, resource availability, and economic development are also strongly influenced by the choice of emissions mitigation strategies in the stabilization cases. The shaded areas in Fig. 5 illustrate the main sources of $\mathrm{CO}_{2}$ reductions in the global energy systems of the mitigation scenarios, compared to the respective baseline scenarios. In all scenarios, three principal contributors were identified by MESSAGE and MACRO as the most cost-effective route to meet the required stabilization target:

- Fuel switching away from carbon-intensive fuels such as coal.

- Scrubbing and removing $\mathrm{CO}_{2}$ in power plants and during the production of synthetic fuels, mainly methanol, and hydrogen.

- Lower energy demand (enhanced energy conservation) of the stabilization case compared to the baseline counterpart, due to higher energy costs in the stabilization cases compared to their baseline scenario counterparts.

In the A2-550 and B2-550 scenarios, the largest contribution comes from structural changes in the energy system. Principally, this is a shift away from coal, which has the highest $\mathrm{CO}_{2}$ emissions per unit of energy. To satisfy the carbon constraint, both scenarios make a pronounced shift to less carbon-intensive resources, and coal's share of primary energy decreases from $26 \%$ in 1990 to $6 \%$ in B2-550 and $17 \%$ in A2-550 by 2100 . See also Fig. 1, where primary energy shares for the baseline scenarios are compared to those for the stabilization scenarios.

In the $\mathrm{A} 1 \mathrm{C}-550$ scenario, $\mathrm{CO}_{2}$ scrubbing is the major source of $\mathrm{CO}_{2}$ emissions reduction. Almost $90 \%$ of the emissions reduction in 2100 is due to scrubbing. Scrubbing occurs at the level of hydrogen and synthetic fuel production, and in the electricity sector. Energy structural changes (the principal contributor to the reduction in $\mathrm{B} 2-550$ and $\mathrm{A} 2-550$ ) play a minor role in $\mathrm{A} 1 \mathrm{C}-550$. The scenario experiences a lock-in into coal as the main future energy source. This is because of the high technology improvement rates in the coal sector, which were already

${ }^{31}$ For the scenarios presented in this paper, a discount rate of $5 \%$ was applied. 
assumed for the $\mathrm{A} 1 \mathrm{C}$ baseline. Even with the penalty that $\mathrm{CO}_{2}$ scrubbing entails in the form of additional costs and electricity losses, scrubbing remains an attractive option in A1C-550.

Carbon scrubbing is also an important reduction source in the A1-550 scenario. More than $50 \%$ of the reduction in $\mathrm{CO}_{2}$ emissions is due to scrubbing. However, in contrast to $\mathrm{A} 1 \mathrm{C}-550$, the main reason for the relatively high share of $\mathrm{CO}_{2}$ scrubbing is not the low cost assumptions for coal-based technologies. In A1, technology cost improvement rates are relatively high $^{32}$ across all technologies, and coal is no exception. The main reason for the high share of scrubbing in A1-550 is rather that the potential for structural changes from A1 to A1-550 is limited. In 2100 , zero-carbon options already contribute more than $70 \%$ to the energy supply in baseline scenario A1 (Fig. 1). To meet the stabilization constraint their share rises further up to $78 \%$ in A1-550, which is already the highest share among the stabilization scenarios (see Fig. 1). Consequently, scrubbing/removal of carbon is needed to decarbonize the remaining fossil energy system, which accounts for no more than $12 \%$ of the total primary share in A1-550. By 2100, 4.7 GtC is scrubbed and $2.1 \mathrm{GtC}$ reduced due to structural changes in A1-550.

In all mitigation scenarios, price-induced energy demand reductions contribute to $\mathrm{CO}_{2}$ emissions reduction. The prices ${ }^{33}$ of energy increase as a result of the applied carbon constraint. The effect of the increased prices is that energy demand and GWP for the stabilization scenarios are reduced, ${ }^{34}$ compared to their baseline counterparts. The emissions reduced due to the demand reductions are illustrated in Fig. 5. The A2-550 scenario shows the highest emissions reductions due to price-induced energy demand reductions (4 GtC in 2100), and A1-550 shows the smallest effect ( $1 \mathrm{GtC}$ in 2100).

\subsubsection{Influence of carbon mitigation on economic growth}

As described in Section 2.2.1, the choice of baseline is critically important in determining the potential for and costs of various mitigation measures. Here we discuss the economic impact of the increased energy costs that are a result of the carbon constraint. Table 3 summarizes the losses of GWP in absolute terms and as shares of the baseline GWPs.

The GWP gap between the stabilization scenarios and their mitigation scenarios ranges from 0.5 to $2.6 \%$ in 2100 . This is comparable to results from similar studies. For example, Edmonds and Richels (1995) report losses of 0.5 to $1 \%$ for a $500 \mathrm{ppm}$ stabilization constraint. Results for a $550 \mathrm{ppmv}$ stabilization case from the 14th Energy Modeling Forum for four different models (CSERGE, CETA, PEF, and CONN) suggest losses between 0.4 and $3.4 \%$ of GWP (EMF14

\footnotetext{
${ }^{32}$ Technology improvement rates (investment, operation, and maintenance costs) for almost all technologies are highest in the A1 scenario and lowest in the A2 scenario (Table 2, and SRES 2000).

${ }^{33}$ As prices, we use shadow-prices calculated by the MESSAGE model.

${ }^{34}$ The price-induced demand and GWP (gross world product) reductions were calculated iteratively. Results from the systems-engineering model MESSAGE and from the macroeconomic equilibrium model MACRO were iterated until consistency between the region's macroeconomic development and its energy use was achieved.
} 
Table 3. Gross world product (GWP) losses from the reference case to the mitigation scenario in 2100

\begin{tabular}{l|c|c|c}
\hline & $\begin{array}{c}\text { GWP } \\
\text { [trillion (1990) US\$] }\end{array}$ & $\begin{array}{c}\text { Absolute losses } \\
\text { [trillion (1990) US\$] }\end{array}$ & $\begin{array}{c}\text { Losses in percent } \\
\text { [relative to baseline GWP] }\end{array}$ \\
\hline A1C-550 & 542 & 8.4 & $1.5 \%$ \\
A1-550 & 547 & 2.8 & $0.5 \%$ \\
A2-550 & 236 & 6.4 & $2.6 \%$ \\
B2-550 & 231 & 4.0 & $1.7 \%$ \\
\hline
\end{tabular}

Compare the absolute GWP numbers in the stabilization cases with those in the baselines: 550 in A1C and $\mathrm{A} 1,243$ in $\mathrm{A} 2$, and 235 trillion (1990) US\$ in B2

1994). These losses are still rather small compared to the GWP increase in the scenarios: in the lowest scenario, GWP in 2100 is 11 times as large as in 1990, and in the highest case as much as 26 times as large. This illustrates that atmospheric carbon concentration stabilization at $550 \mathrm{ppmv}$ is possible at moderate costs.

\section{Robust energy technology strategies}

In this section, we analyze the robustness of technology portfolios for the key sectors of electricity generation and transport, under a wide range of possible future socioeconomic and technological outcomes. In particular, we explore the robustness of future technology strategies by comparing the composition and structure of the technology portfolios found in the different scenario sets described in the above sections: the non-climate-policy scenarios (A1, A1T, A1C, A1G, B2, A2, B1, B1G, B1T), the sustainable development scenarios without explicit climate policies (A1T, B1, B1G, B1T), and the $\mathrm{CO}_{2}$ mitigation/stabilization scenarios (A1-550, A1C-550, B2-550, A2-550). This also provides valuable information on the robustness of $\mathrm{CO}_{2}$ mitigation options. For related information on assumed technology costs in the scenarios, please refer to Chapter 4 of the Special Report on Emissions Scenarios (SRES, 2000).

Due to the large number of technologies (around 400) specified in the MESSAGE scenario quantifications (see Appendix I), in this section we present results for aggregated technology data for the transport and the electricity generation sectors on the world level only. We show ranges (minimum, maximum) and averages of future market shares within the respective sectors and across all three scenario sets (see Figs. 6, 7, 8, and 9). We interpret the frequent occurrence of a technology in the portfolio as a strong agreement on the technology's promising future potential. Hence, a technology that contributes much to the technology portfolio across all scenarios is considered to be a robust future technology option (in Figs. 6 to 9, this is the case when a technology shows a high minimum share). Small ranges around the average market share of a technology indicate a high agreement (high certainty) on the future share itself (i.e., when the minimum and the maximum are close to the average of a technology in Figs. 6 to 9 ). In other words, especially robust options with low uncertainty regarding their future shares are those technologies that show high minimum shares and small deviations around their average shares in Figs. 6 to 9. 


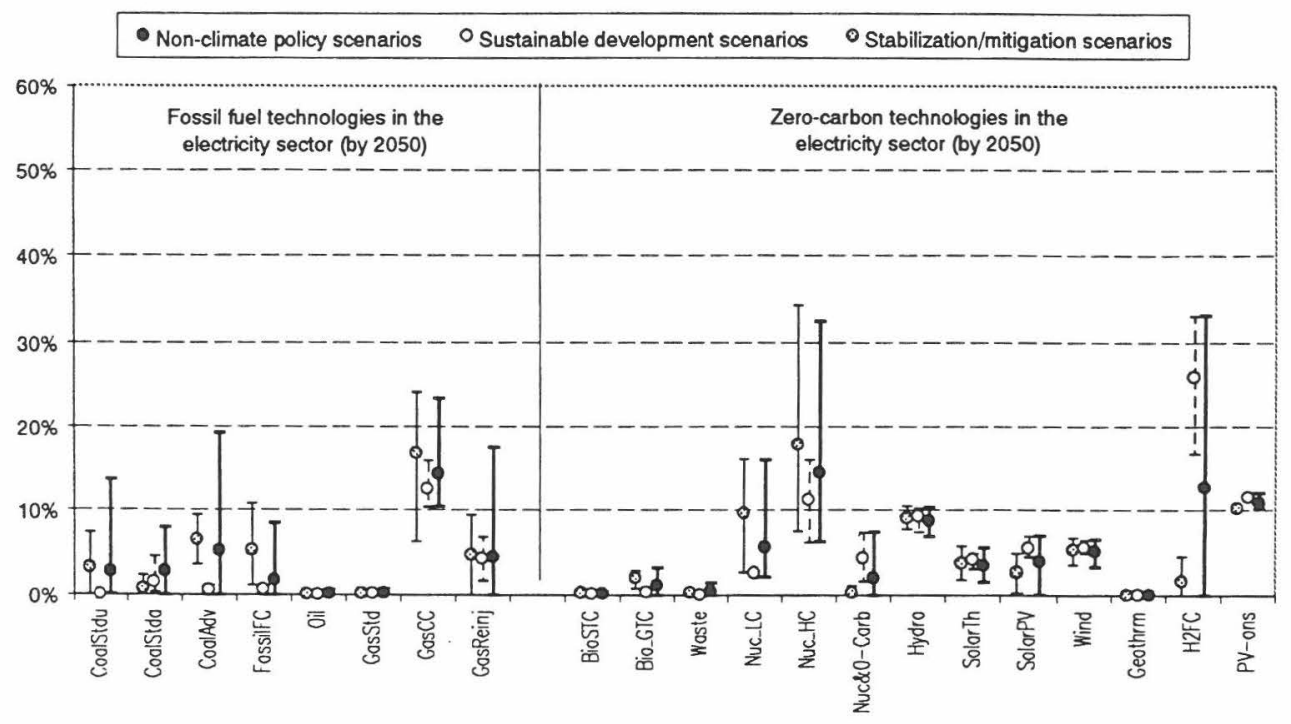

Fig. 6. Ranges and averages of market shares (in percent) of the global electricity sector for aggregate technologies in 2050. Abbreviations used to indicate the aggregate technologies on the horizontal axis are explained in Appendix II

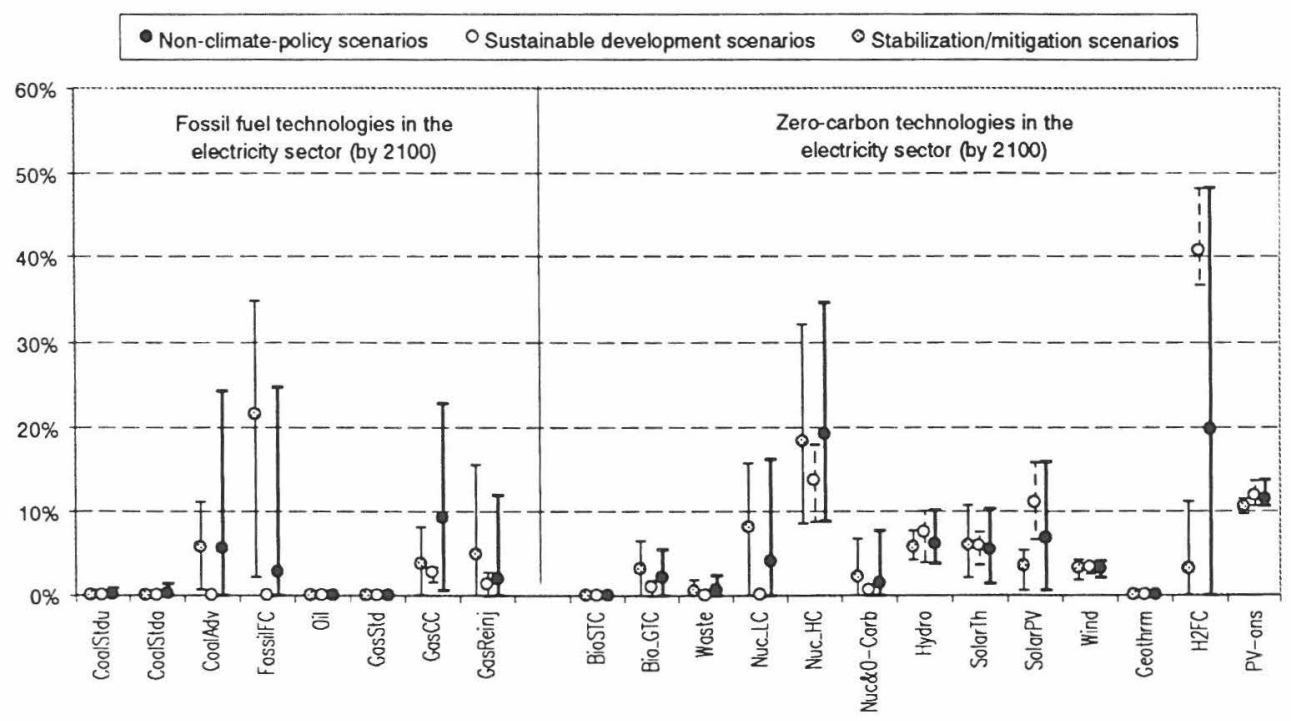

Fig. 7. Ranges and averages of market shares (in percent) of the global electricity sector for aggregate technologies in 2100. Abbreviations used to indicate the aggregate technologies on the horizontal axis are explained in Appendix II 

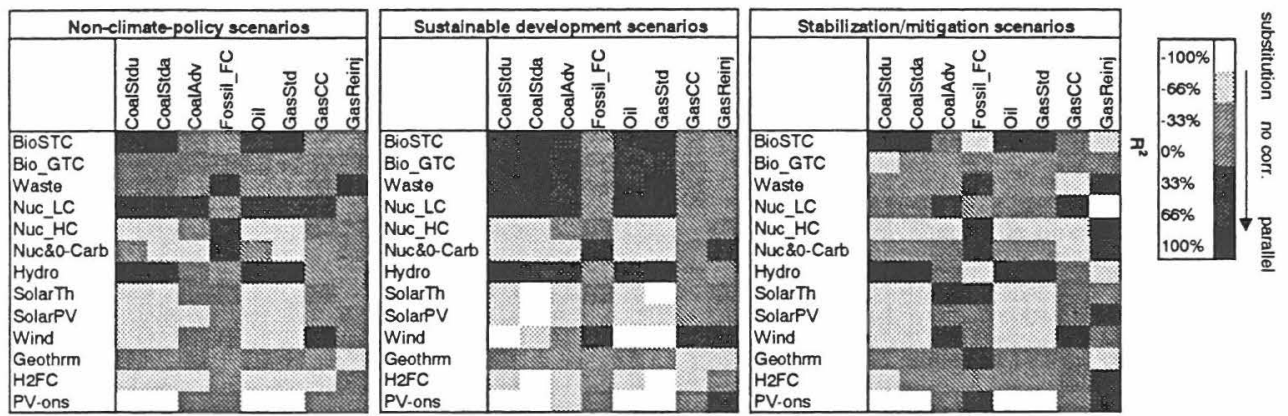

Fig. 8. Correlation ${ }^{40}$ matrices $\left(\mathrm{R}^{2}\right)$ for market shares of (aggregate) zero-carbon technologies vs. fossil fuel technologies in the global electricity sector from 2000 to 2100 . Abbreviations used to indicate the aggregate technologies on the axes are explained in Appendix II. Black squares $\left(\mathrm{R}^{2}\right.$ close to $100 \%$ ) denote technology pairs where market shares evolve positively linear (i.e., in parallel and in the same direction), whereas white squares $\left(\mathrm{R}^{2}\right.$ close to $-100 \%$ ) show a negatively linear relationship, i.e., technologies are substitutes for each other throughout the $21^{\text {st }}$ century

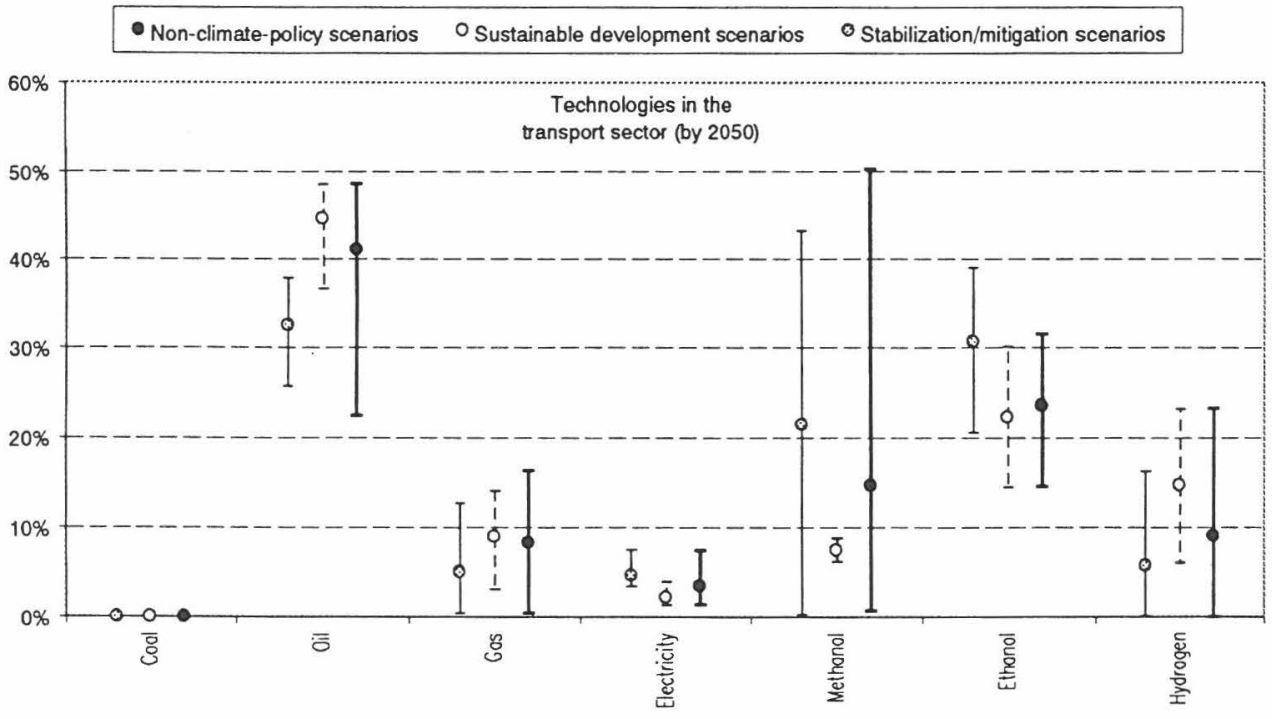

Fig. 9. Ranges and averages of market shares of the global transport sector for aggregate technologies in 2050

\subsection{Global electricity sector}

Electricity generation in 1990 was dominated by fossil fuels ( $65 \%$ of total electricity output), supplemented by $17 \%$ nuclear power and $18 \%$ hydro power. In almost all scenarios analyzed here, the structure of the electricity sector and the corresponding electricity technology portfolio changes significantly throughout 
the $21^{\text {st }}$ century. Figures 6 and 7 illustrate the electricity market shares of technologies in the scenarios for the years 2050 and 2100, respectively.

Figures 6 and 7 illustrate the ranges (difference between minimum and maximum market share) of individual technologies for the scenario sets described in Section 2, that is, the non-climate-policy scenarios, the sustainable development scenarios, and the $\mathrm{CO}_{2}$ mitigation/stabilization scenarios. The set of non-climatepolicy scenarios show the largest ranges of market shares for almost all technologies..$^{35}$ These ranges indicate the high uncertainty for the adoption of specific electricity technology portfolios. This also explains the wide range of resulting $\mathrm{CO}_{2}$ emissions for non-climate-policy scenarios (Fig. 2). The respective ranges for the $\mathrm{CO}_{2}$ mitigation scenarios and for the sustainable development scenarios are smaller. Measures to reduce $\mathrm{CO}_{2}$ emissions, mitigate local air pollution, etc. drive the energy technology mix in the direction of higher shares of zero-carbon technologies. This increases the agreement on the zero-carbon technologies among these scenarios.

In the course of the $21^{\text {st }}$ century, traditional electricity generation technologies $^{36}$ based on fossil fuels are phased-out across all scenarios (Fig. 7). In particular, it is the gas combined-cycle (GasCC, see Fig. 6) technology that bridges the transition to more advanced fossil and zero-carbon technologies. In many nonclimate-policy scenarios and in some stabilization scenarios, advanced fossilbased technologies may become an important option by $2100 .{ }^{37}$ The high uncertainty regarding fossil technologies in the two scenario sets is illustrated by the comparatively large ranges for fossil-based fuel cells, for gas combinedcycle, ${ }^{38}$ and for advanced coal technologies (e.g., IGCC), shown in Fig. 7. In contrast to that, the sustainable development scenarios agree more strongly on the future of fossil fuel technologies in the electricity sector. In these scenarios, the only relevant fossil fuel in 2100 is gas, and it's market share in 2100 is rather small compared to non-fossil options (Fig. 7).

Comparatively robust conclusions may be drawn from Figs. 6 and 7 concerning the adoption of zero-carbon electricity generation technologies in the sustainable

\footnotetext{
${ }^{35}$ There are two noticeable exceptions (Figs. 6 and 7), where the ranges for the $\mathrm{CO}_{2}$ mitigation scenarios are larger than those for the non-climate-policy scenarios: gas combined-cycle in 2050 , and fossil fuel cells in 2100 . In some mitigation cases, gas combined-cycle power plants are used to substitute less efficient and more carbon-intensive electricity generation from coal. Therefore, in some cases it is possible that the maximum contribution in the mitigation scenarios is even larger than that for the non-policy scenarios. For some other mitigation scenarios, highly efficient fuel cells in combination with carbon scrubbing play an important role. Hence, the maximum contribution of fossil fuel cells may even exceed their contribution in the nonclimate-policy scenarios.

${ }^{36}$ The traditional electricity generation technologies based on fossil fuels are CoalStdu, CoalStda, Oil, and GasStd. For an explanation of the abbreviations, see Appendix II.

${ }^{37}$ Note that in the stabilization scenarios, fossil electricity generation generally occurs in combination with carbon scrubbing.

${ }^{3 *}$ Here we refer to gas combined-cycle power plants with and without $\mathrm{CO}_{2}$ emissions reinjection for enhanced oil recovery at field $\left(\mathrm{CO}_{2}\right.$ re-injection is a possible means of using gas for electricity generation without emitting $\mathrm{CO}_{2}$ in the atmosphere).
} 
development scenarios. The sustainable development scenarios agree in that the major future contributors to electricity production are hydrogen-based fuel cells. ${ }^{39}$ Their minimum market share of total electricity generation (across all sustainable development scenarios) increases from 18\% in 2050 to $35 \%$ in 2100 . In contrast, the mitigation scenarios show relatively small market shares for these technologies (up to $11 \%$ ), and their occurrence is highly uncertain in nonclimate-policy scenarios (ranging from $0 \%$ to $49 \%$ in 2100 ).

Across all scenarios there is a strong agreement concerning minimum future shares for inherently safe future nuclear technologies (around $9 \%$ in 2100 , see "Nuc_HC" in Fig. 7). Their contributions range up to some 35\% in non-climatepolicy scenarios and some mitigation scenarios. The maximum share of sustainable development scenarios is significantly less at about $19 \%$.

A robust conclusion across most scenarios is that there is no other single dominant technology except hydrogen fuel cells. Relatively uniform sector diversification leads to slim distributions of zero-carbon market shares for electricity from hydro, wind, solar and biomass technologies. However, the moderate individual market shares sum up to substantial amounts of zero-carbon power production. As shown in Figs. 6 and 7, for these technologies the maximum and minimum shares are close to the averages. We interpret this as a "robust" portfolio mix of future zero-carbon technologies in the electricity sector. This may be observed especially for the sustainable development scenarios, and to a lesser extent for the $\mathrm{CO}_{2}$ stabilization scenarios as well.

Figures 6 and 7 present only ranges of technology market shares between scenarios, but do not answer the questions of which technologies' market shares increase in line with each other, or which technologies are substituted for each other across all scenarios. Correlation matrices specify the correlation ${ }^{40}\left(R^{2}\right)$ between the market shares of technologies. For example, Fig. 8 shows such correlation matrices for pairs of (aggregate) zero-carbon vs. fossil fuel technologies in the electricity sector from 2000 to 2100 , presented for all three scenario groups. The white squares denote $\mathrm{R}^{2}$ lower than $-80 \%$, e.g. in all scenarios $\mathrm{PV}$ onsite technologies increasingly substitute conventional coal, oil, and gas technologies (Fig. 8). The black squares denote $\mathrm{R}^{2}$ higher than $80 \%$ and mean that the market shares of the two technologies evolve in parallel (e.g., hydro power plants and conventional coal power plants ${ }^{41}$ ). Squares with a medium grey colour denote correlation pairs with $\mathrm{R}^{2}$ close to zero (Fig. 8). For example, gas com-

\footnotetext{
${ }^{39}$ Note that hydrogen fuel cells do not emit any carbon at the level of electricity production. However, the process of hydrogen production itself might cause carbon emissions. This is the case when the hydrogen is produced from fossil fuels. Consequently, hydrogen fuel cells may only be regarded as a truly zero-carbon electricity option when zero-carbon fuels are also used for the hydrogen production itself.

${ }^{40}$ This correlation is often measured with a so-called $\mathrm{R}^{2} \cdot \mathrm{R}^{2}=60 \%$ for a correlation between technology a and b may be interpreted to mean that about $60 \%$ of the market share variations for technologies a and $\mathrm{b}$ could be described by a positive, linear relationship.

${ }^{41}$ Note that we analyze market shares only, i.e., declining global market shares for hydro power may still involve significantly increasing hydro power capacities.
} 
bined-cycle power plants (GasCC) fall into this category (Fig. 8), because they serve as transition technologies. Their market share first increases at a faster rate than many zero-carbon technologies, but in the second half of the $21^{\text {st }}$ century GasCC experience decreasing global market shares compared to still increasing market shares of zero-carbon technologies. Despite all these similarities across the three scenario groups, the sustainable development scenarios show the most clear-cut pattern in the correlation matrix, i.e., these sustainable development scenarios show a continuous replacement of the now dominating fossil fuel electricity generation technologies with new renewables such as solar, wind, hydrogen fuel cells. In this sense the correlation matrices visualize technology clusters in Fig. 8.

\subsection{Transport sector}

Another key sector in terms of future global carbon dioxide emissions is the rapidly increasing global transport sector. In a similar way as above, this section analyzes shares of and correlations between main energy fuels in the transport sector (Figs. 9, 10, and 11).

There is a strong agreement across all scenarios that today's dominance of oil products in the transport sector will vanish in the medium to long-term future (see Figs. 9 and 10). In the medium-term future up to 2050, oil products, synthetic liquids from biomass (ethanol), and synthetic liquids from fossil fuels (methanol) are the main contributors (Fig. 9). Already in 2050, some scenarios exhibit a further diversification with an increasing diffusion of gas, electricity, and hydrogen-based technologies. In the later decades of the century, substitution of oil by

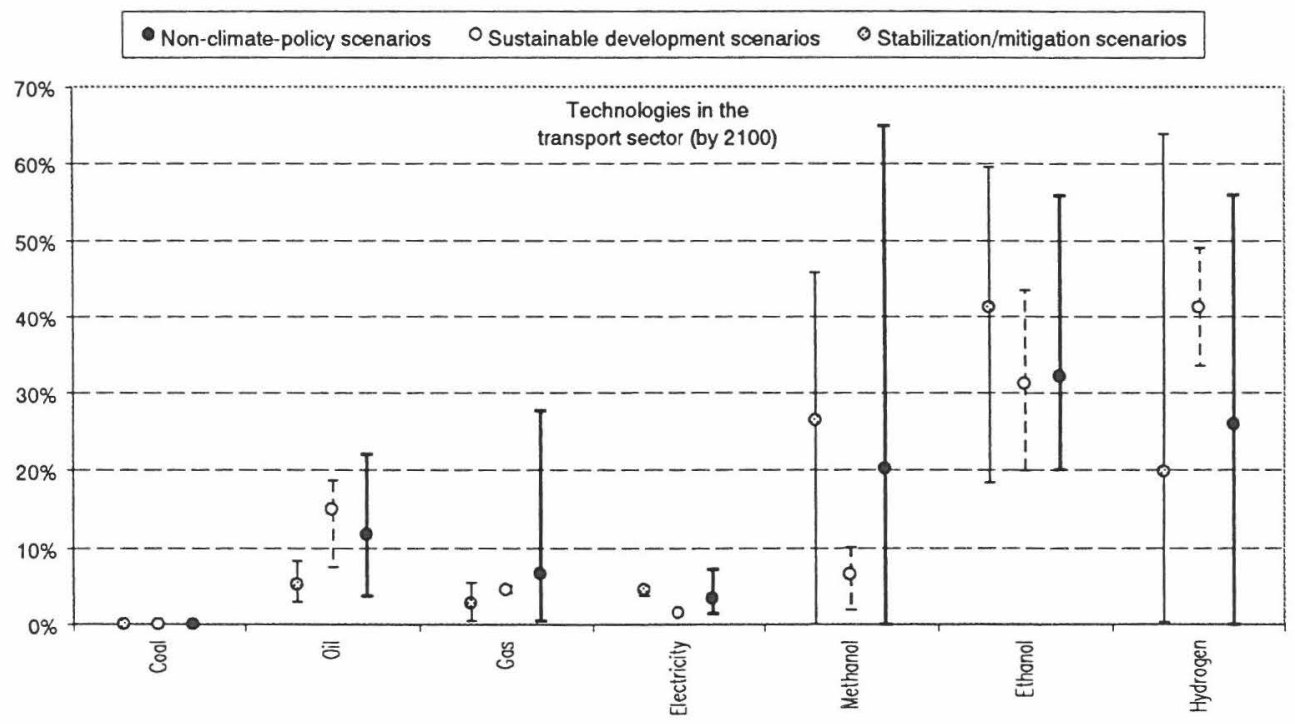

Fig. 10. Ranges and averages of market shares of the global transport sector for aggregate technologies in 2100 

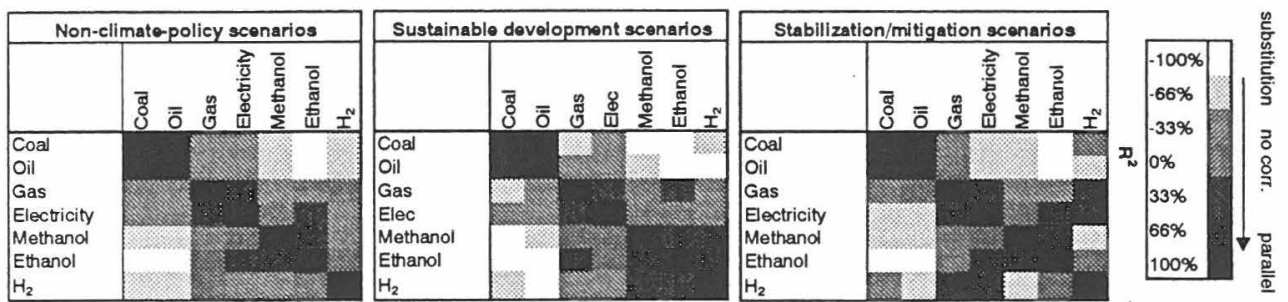

Fig. 11. Correlation matrices $\left(\mathrm{R}^{2}\right)$ for market shares of transport fuels from 2000 to 2100 . Abbreviations used to indicate the aggregate technologies on the horizontal axis are explained in Appendix II. Black squares ( $\mathrm{R}^{2}$ close to $100 \%$ ) denote pairs of fuels where market shares evolve positively linear (i.e., in parallel and in the same direction), whereas white squares $\left(\mathrm{R}^{2}\right.$ close to $-100 \%$ ) show negatively linear relationships, i.e., transport fuels are substitutes for each other throughout the $21^{\text {st }}$ century. Transition fuels show small correlations $\left(\mathrm{R}^{2}\right.$ close to 0$)$

ethanol and methanol is increasingly complemented by hydrogen (see Fig. 1). For non-climate-policy scenarios and stabilization scenarios, ethanol $(>18 \%$ in all scenarios in 2100) seems to be a more robust bet than methanol and hydrogen. ${ }^{42}$ Conversely, hydrogen and ethanol seem to be the more promising future technologies for sustainable development scenarios.

Compared to Figs. 6 and 7, Figs. 9 and 10 show larger ranges for future technology market shares. We interpret this to indicate a higher uncertainty concerning future technology portfolios in the transport sector than in the electricity generation sector.

The correlation matrix (Fig. 11) for the fuels in the transport sector shows surprisingly similar patterns for all three scenario groups, although the future market shares of the various transport fuels vary substantially. Note also the appearance of a methanol/ethanol/ $\mathrm{H}_{2}$ technology cluster, in particular in the sustainable development scenarios. Finally, the high correlation between gas and electricity in the transport sector and that between coal and oil (Fig. 11) should not be overinterpreted, since the absolute market shares of coal, electricity, and gas in the global transport sector are relatively small in all scenarios (Figs. 9 and 10 ), with only few exceptions (such as in gas scenarios). Also note that the share of electricity in transport depends on the assumed share of public transportation which is mainly a public policy choice. ${ }^{43}$

\footnotetext{
${ }^{42}$ Figures 9 and 10 show a very small range for possible shares of transport technologies driven from the electricity grid, since no scenario in our sample explored increased large-scale expansion of electrified public transportation systems at the expense of individual mobility. This is rather a model input than a model output.

${ }^{43}$ The scenarios presented in this paper illustrate our belief that the strive for individual mobility will continue to be a dominating force with rising incomes. However, the scenarios also assume certain saturation levels, e.g., even in the most extreme high growth A1 scenarios where GDP per capita levels converge rapidly, China's energy use in the transport sector will not significantly surpass the respective per capita level of the U.S. today.
} 


\section{Climate change}

What are the possible climate change consequences of selecting one technology strategy and therefore one of the emission scenarios (described above) over another? As an indicator of the extent of climate impact, we discuss global mean temperature change in this section. ${ }^{44}$

For all scenarios described in this paper, estimations of all anthropogenic sources of the following emissons were included in the analysis: $\mathrm{CO}_{2}, \mathrm{CH}_{4}, \mathrm{~N}_{2} \mathrm{O}$, $\mathrm{SO}_{2}, \mathrm{CFC} / \mathrm{HFC} / \mathrm{HCFC}, \mathrm{PFC}, \mathrm{SF}_{6}, \mathrm{CO}, \mathrm{VOCs}$, and NOx. Whereas energy-related emissions are direct output of the MESSAGE-MACRO model, non-energysector emissions were estimated with a spreadsheet model, using corresponding land-use change model runs with equivalent input assumptions from the AIM model (see Section 2, and Jiang et al. 2000; Riahi and Roehrl 2000). Data for perfluorocarbons (PFCs), sulphur hexafluoride $\left(\mathrm{SF}_{6}\right)$, and hydrofluorocarbons (HFCs) are taken from Fenhann (2000), and emission trajectories for ozone depleting substances covered by the Montreal Protocol (e.g., CFCs, HCFCs) are also taken from Fenhann (2000), based on the Montreal Protocol scenario (A3) from the 1998 Scientific Assessment of Ozone Depletion (WMO/UNEP 1998). Using these emissions trajectories as inputs to the climate model MAGICC (version 2.3; Wigley and Raper 1997), estimates can be made of possible climate change consequences. $^{45}$

Figure 12 shows global mean temperature changes due to all gases relative to $1990 .^{46}$ In 2100, global mean temperature change shows a large range, from 1.6 to $1.9^{\circ} \mathrm{C}$ for the sustainable development scenarios, from 2.0 to $3.0^{\circ} \mathrm{C}$ for the baseline reference scenarios, and from 1.8 to $2.1^{\circ} \mathrm{C}$ for the $\mathrm{CO}_{2}$ mitigation scenarios (that stabilize at 550 ppmv in 2100). Up to about 2050, however, global mean temperature change is not very different for all the scenarios (Fig. 12), which is due to the combined inertia of the energy system and the climate system, and a balancing effect of sulfur emissions. As a matter of fact, decreasing sulfur emissions (Fig. 3) enhance radiative forcing and $\mathrm{GHG}$-induced warming, whereas decreasing $\mathrm{CO}_{2}$ emissions decrease radiative forcing. Since $\mathrm{GHG}$ emissions are generally lowest in the sustainable development scenarios, which also have the lowest $\mathrm{SO}_{2}$ emissions, the two effects counterbalance each other until $\mathrm{CO}_{2}$ emissions start differing substantially among the different scenarios and $\mathrm{SO}_{2}$ emissions have reached a very low level (from which not much further sulfur reduction is possible).

\footnotetext{
${ }^{44}$ We could just as well discuss radiative forcing, or sea level rise. One of the most obvious differences in these indicators is illustrated by different time lags between radiative forcing, global mean temperature change, and sea level rise.

${ }_{45}$ Model version 2.3 supports regionalized (three world regions) $\mathrm{SO}_{2}$ emissions input data, which are needed to calculate the regionally different cooling effects of sulfate aerosols. For radiative forcing we use the latest parameterizations reported in Myhre et al. (1998). The other model input parameters for MAGICC used here are similar to those used by the IPCC in the Second Assessment Report (IPCC 1996).

${ }^{46}$ Note that radiative forcing shows a similar pattern to global mean temperature change, where the latter is subject to a time lag.
} 


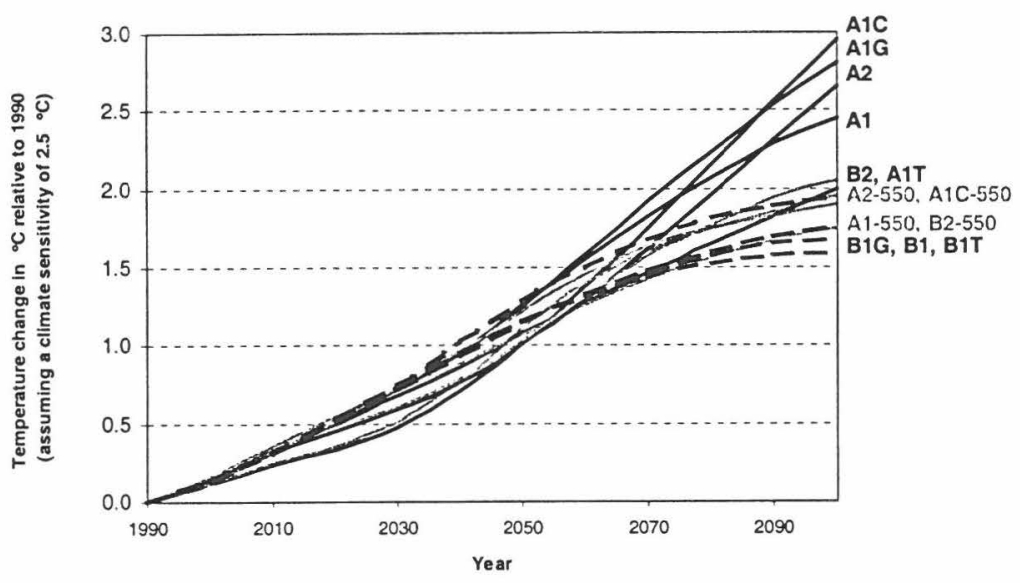

Fig. 12. Global mean temperature changes in ${ }^{\circ} \mathrm{C}$ assuming an intermediate "best guess" climate sensitivity of $2.5^{\circ} \mathrm{C}$ for a doubling of $\mathrm{CO}_{2}$ concentration

In contrast to the other scenarios, the coal-intensive baseline $\mathrm{A} 1 \mathrm{C}$ and $\mathrm{A} 2$ scenarios first experience a rapid increase in global $\mathrm{SO}_{2}$ emissions until 2040, and then an eventual decline (Fig. 3). Until 2090 this produces a strong negative radiative forcing (or cooling) effect in $\mathrm{A} 1 \mathrm{C}$ and $\mathrm{A} 2 .^{47}$ As a consequence, global mean temperature change for $\mathrm{A} 1 \mathrm{C}$ and $\mathrm{A} 2$ is lower than in the other cases until about 2050, although $\mathrm{CO}_{2}$ emissions in the $\mathrm{A} 1 \mathrm{C}$ and $\mathrm{A} 2$ baselines are the highest among all the scenarios examined in this paper.

These estimates are for a "best guess" climate sensitivity of $2.5^{\circ} \mathrm{C}$ (i.e. $2.5^{\circ} \mathrm{C}$ warming for a doubling of atmospheric $\mathrm{CO}_{2}$ levels (IPCC 1996)). However, the climate sensitivity parameter is highly uncertain. Often lower bounds for climate sensitivity parameters of $1.5^{\circ} \mathrm{C}$ and higher bounds of $4.5^{\circ} \mathrm{C}$ are suggested (IPCC 1996), which would change our results dramatically. For example, if we use these bounds for climate sensitivity to calculate an "uncertainty range" for global mean temperature change in 2100 (relative to 1990), this range is from $1.4^{\circ} \mathrm{C}$ to $2.9^{\circ} \mathrm{C}$ for the B2 baseline scenario alone, compared to a "best guess" estimate for B2 of $2.0^{\circ} \mathrm{C}$. Note that this "uncertainty range" for $\mathrm{B} 2$ is as large as the range of best guesses over all scenarios $\left(1.6^{\circ} \mathrm{C}\right.$ for $\mathrm{B} 1 \mathrm{~T}$ to $3.0^{\circ} \mathrm{C}$ for $\mathrm{A} 1 \mathrm{C}$ in 2100$)$ discussed in this paper.

\section{Summary and conclusion}

In this paper, we have analyzed the robustness of different technology portfolios under a wide range of possible future socioeconomic and technological outcomes, illustrated by 13 global energy-economic development scenarios for the

\footnotetext{
${ }^{47}$ Summing the direct and indirect effects of $\mathrm{SO}_{4}$.
} 
$21^{\text {st }}$ century. For this purpose we compared three different groups of scenarios: non-climate-policy scenarios that do not assume direct climate policies, and are part of the IPCC's Special Report on Emissions (SRES 2000), sustainable development scenarios, which form a subset of the latter scenario group, and are based on a range of non-climate-policies that generally ensure emissions comparable to the lower bound emissions range of the non-climate-policy scenarios, and $\mathrm{CO}_{2}$ mitigation scenarios, which assume climate policies that are aimed at stabilizing atmospheric $\mathrm{CO}_{2}$ concentrations at a level of 550 ppmv shortly after 2100 .

The non-climate-policy scenarios explore alternative development pathways of socioeconomic development and technological change. The range of emissions that results from varying technological change (e.g., the range from $\mathrm{A} 1 \mathrm{~T}$ to $\mathrm{A} 1 \mathrm{C}$ ) is as large as the range of emissions spanned by varying both technological improvement rates and socioeconomic development (e.g., the range from B1 to A2). This illustrates the importance of technological change as one of the major driving forces of future emissions.

Baseline assumptions on technological development, resource availability, and economic development strongly influence the choice of emissions mitigation strategies in the stabilization/mitigation cases. Of all the available $\mathrm{CO}_{2}$ emissions reduction measures, no one single measure will be sufficient for the timely development, adoption, and diffusion of mitigation options sufficient to stabilize the atmospheric composition. Rather, a portfolio based on technological change, economic incentives, and institutional frameworks will be adopted. Three major contributors to the emissions reduction of the $\mathrm{CO}_{2}$ mitigation scenarios could be identified: carbon scrubbing and removal, structural shifts in the energy structure away from carbon-intensive fuels (such as coal), and price induced demand reductions due to increased energy prices in the mitigation scenarios. The gross world product gap between the stabilization scenarios and their respective mitigation scenarios ranges from $0.5 \%$ to $2.6 \%$ in 2100 . Compared to the economic growth of the scenarios the GWP losses are very small, which indicates that atmospheric carbon concentration stabilization at $550 \mathrm{ppmv}$ is possible at modest costs. The losses were highest in A1C-550, a high-growth scenario that experiences a strong lock-in into a coal-based, synthetic fuel economy.

The central result of this paper is the conclusions on which energy technology portfolios are "robust" under a wide range of possible future socioeconomic and technological outcomes. The technology robustness analysis shows which traditional electricity generation technologies based on fossil fuels are phased out across all scenarios in the course of the $21^{\text {st }}$ century. In particular, it is the gas combined-cycle technology that bridges the transition to more advanced fossil and zero-carbon technologies. There is also a high agreement concerning the adoption of zero-carbon electricity technologies in the sustainable development scenarios, which indicates that the major future contributors to electricity production are hydrogen-based fuel cells. A robust conclusion across most scenarios is that there is no single dominant technology except hydrogen fuel cells. Relatively uniform sector diversification leads to slim distributions of zero-carbon 
market shares for electricity from hydro, wind, solar, and biomass technologies. In the transport sector, today's dominance of oil products will vanish in the medium to long-term future, however, it remains uncertain which technologies are the most promising to replace the gasoline-powered automobile in the long run. We find that even in fossil-fuel-intensive scenarios, the long-term technology portfolio needs to include improvements in zero-carbon options and gas-related technologies and infrastructures. Innovative "transitional" strategies of using natural gas as a "bridge" toward a carbon-free hydrogen economy (including $\mathrm{CO}_{2}$ sequestration) are also at a premium in a possible future world with low emissions.

To calculate expected global mean temperature change for the different scenarios, estimations for all anthropogenic sources of $\mathrm{CO}_{2}, \mathrm{CH}_{4}, \mathrm{~N}_{2} \mathrm{O}, \mathrm{SO}_{2}, \mathrm{CFC}$ / $\mathrm{HFC} / \mathrm{HCFC}, \mathrm{PFC}, \mathrm{SF}_{6}, \mathrm{CO}, \mathrm{VOCs}$, and $\mathrm{NO}_{x}$ were calculated. Up to 2050 , global mean temperature change is not very different for all the scenarios, which is due to the combined inertia of the energy system and the climate system, and a balancing effect of sulfur emissions. Temperature change in 2100 shows a large range, from 1.6 to $1.9^{\circ} \mathrm{C}$ for the sustainable development scenarios, from 2.0 to $3.0^{\circ} \mathrm{C}$ for the baseline reference scenarios, and from 1.8 to $2.1^{\circ} \mathrm{C}$ for the $\mathrm{CO}_{2}$ mitigation scenarios. Controls of sulfur emissions could amplify possible climate change in the medium-term perspective. On the other hand, for the coalintensive $\mathrm{A} 1 \mathrm{C}$ and $\mathrm{A} 2$ scenarios, global mean temperature change is lower than in the other cases until about 2050. Therefore, tradeoffs are likely to persist for environmental policies throughout the $21^{\text {st }}$ century. Note that hedging strategies are particularly important, as climate model uncertainties are larger than the range of best guess climate change estimates for emissions trajectories from futures that differ widely in terms of their socioeconomic, institutional, and technological development.

Finally, we suggest future international climate change agreements to take a long-term view of actively managing risk related to future socioeconomic, institutional, and technological development.

\section{References}

Barro RJ, Sala-I-Martin X (1995) Economic growth. McGraw-Hill, New York

de Vries B, Bollen J, Bouwman L, den Elzen M, Janssen M, Kreileman E (2000) Greenhouse-gas emissions in an equity-, environment- and service-oriented world: an IMAGE-based scenario for the next century. Technological Forecasting and Social Change 63(2-3)

Edmonds J, Richels R (1995) The economics of stabilizing atmospheric $\mathrm{CO}_{2}$ concentrations. Energy Policy 23(4/5):373-370

EMF14 (Energy Modeling Forum) (1994) Integrated assessment of climate change models. First round of scenario results, available from L. Schrattenholzer, International Institute for Applied Systems Analysis, 2361 Laxenburg, Austria

Fenhann J (2000) Industrial non-energy, non- $\mathrm{CO}_{2}$ greenhouse gas emissions. Technological Forecasting and Social Change 63(2-3)

Huntington S (1997) The clash of civilizations and the remaking of world order. Simon \& Schuster, New York

IPCC (Intergovernmental Panel on Climate Change) (1995) Climate change 1994. Intergovernmental Panel on Climate Change, Cambridge University Press 
IPCC (Intergovernmental Panel on Climate Change) (1996) Climate change 1995: impacts, adaptations, and mitigation of climate change: scientific-technical analyses. In: Watson RT, Zinyowera MC, Moss RH (eds) Contribution of Working Group II to the Second Assessment Report of the Intergovernmental Panel on Climate Change, Cambridge University Press

Jiang K, Masui T, Morita T, Matsuoka Y (2000) Long-term GHG emission scenarios for Asia-Pacific and the world. Technological Forecasting and Social Change 63(2-3)

Lazarus ML, Greber L, Hall J, Bartels C, Bernow S, Hansen E, Raskin P, von Hippel D (1993) Towards a fossil-free energy future: the next energy transition. A technical analysis for Greenpeace International. Stockholm Environmental Institute Boston Center, Boston

Lutz W, Sanderson W, Scherbov S (1996) World population scenarios in the $21^{\text {st }}$ century. In: The future population of the world: what can we assume today? Earthscan, London, 361-396

Lutz W, Sanderson W, Scherbov S (1997) Doubling of world population unlikely. Nature 387(6635):803-805

Maddison A (1993) Monitoring the world economy 1820-1992. Development Centre of the Organisation for Economic Co-operation and Development, Paris

Marchetti C (1989) How to solve the $\mathrm{CO}_{2}$ problem without tears. International Journal Hydrogen Energy 14:493-506

Marland G, Boden TA, Andres RJ, Brenkert AL, Johnston C (1999) Global, regional, and national $\mathrm{CO}_{2}$ emissions. In: Trends: a compendium of data on global change. Carbon Dioxide Information Analysis Center, Oak Ridge National Laboratory, U.S. Department of Energy, Oak Ridge

Messner S, Schrattenholzer L (1999) MESSAGE-MACRO: linking an energy supply model with a macroeconomic module and solving it iteratively. Energy (in press)

Messner S, Strubegger M (1995) User's guide for MESSAGE III, WP-95-69., International Institute for Applied Systems Analysis, Laxenburg

Messner S, Strubegger M (1991) User's guide to CO2DB: The IIASA CO2 Technology Data Bank version 1.0, working paper-91-31a, International Institute for Applied Systems Analysis, Laxenburg

Myhre G, Highwood EJ, Shine KP, Stordal F (1998) New estimates of radiative forcing due to wellmixed greenhouse gases. Geophysical Research Letters 25(14):2715-2718

Nakicenovic N, Grübler A, Inaba A, Messner S, Nilsson S, Nishimura Y, Rogner H.-H., Schäfer A, Schrattenholzer L, Strubegger M, Swisher Y, Victor D, Wilson D (1993) Long-term strategies for mitigating global warming. Energy 18(5) (special issue)

Nakicenovic N, Grübler A, McDonald A (eds) (1998a) Global energy perspectives. Cambridge University Press, Cambridge

Nakicenovic N, Amann M, Fischer G (1998b) Global energy supply and demand and their environmental effects. Report to the Central Research Institute of the Electric Power Industry, International Institute for Applied Systems Analysis, Laxenburg

Nakicenovic (ed) (2000) Global greenhouse gas emissions scenarios: modeling approaches and implications. Technological Forecasting and Social Change 63(2-3)

Riahi K, Roehrl RA (2000) Greenhouse gas emissions in a dynamics-as-usual scenario of economic and energy development. Technological Forecasting and Social Change 63(2-3)

Roehrl RA, Riahi K (2000) Technology dynamics and greenhouse gas emissions mitigation-a cost assessment. Technological Forecasting and Social Change 63(2-3)

Rogner H-H (1997) An assessment of world hydrocarbon resources. Annual Review of Energy and the Environment 22:217-262

SRES (2000) Special report on emissions scenarios (SRES) for the Intergovernmental Panel on Climate Change. Cambridge University Press

Thurow L (1996) The future of capitalism. Penguin New York

UN (United Nations) (1998) World population projections to 2150. United Nations Department of Economic and Social Affairs Population Division, New York

Wigley TML, Raper SCB (1997) Model for the assessment of greenhouse-gas-induced climate change (MAGICC Version 2.3). The Climate Research Unit, University of East Anglia, UK

Wigley TR, Richels R, Edmonds J (1996) Economic and environmental choices in the stabilization of atmospheric $\mathrm{CO}_{2}$ concentrations. Nature 359:240-243

WMO (World Meteorological Organisation)/UNEP (United Nations Environment Programme) (1998) Scientific assessment of ozone depletion: 1998. WMO Global Ozone Research \& Monitoring, Geneva 


\section{Appendix I}

\section{Modeling framework}

This Appendix briefly summaries the main characteristics of the modeling framework that was used by the authors to quantify the illustrative scenarios (i.e., alternative future pathways) of the global energy system and GHG emissions presented in this paper. For a more detailed description of the model methodology used, please see Riahi and Roehrl (2000), Roehrl and Riahi (2000), and Nakicenovic (ed.) (2000).

Figure 13 shows the principal models and data sets that were used. These include the Scenario Generator (SG) (Nakicenovic et al. 1998a and b), the bottom-up energy systems engineering model MESSAGE $^{4}$ (Messner and Strubegger 1995), the top-down macroeconomic model MACRO (Messner and Schrattenholzer 1999). The climate impact model MAGICC ${ }^{5}$ (Wigley and Raper 1997), and several databases, including the CO2DB (Messner and Strubegger 1991).

The Scenario Generator (SG) is a global simulation model, and it is the starting point for any quantification of economic and energy development scenarios. The SG provides common, consistent input data for MESSAGE and MACRO. Exogenous inputs to the SG are future population trajectories for 11 world regions used by MESSAGE plus key parameters determining regional per capita GDP growth. The SG uses a set of regression equations from historical economic and energy data to estimate regional final energy trajectories, which are then disaggregated into the six demand sectors used by MESSAGE.

The Systems Engineering Model MESSAGE (version IV) is a systems engineering optimization model used for medium- to long-term energy system planning and policy analysis. The model

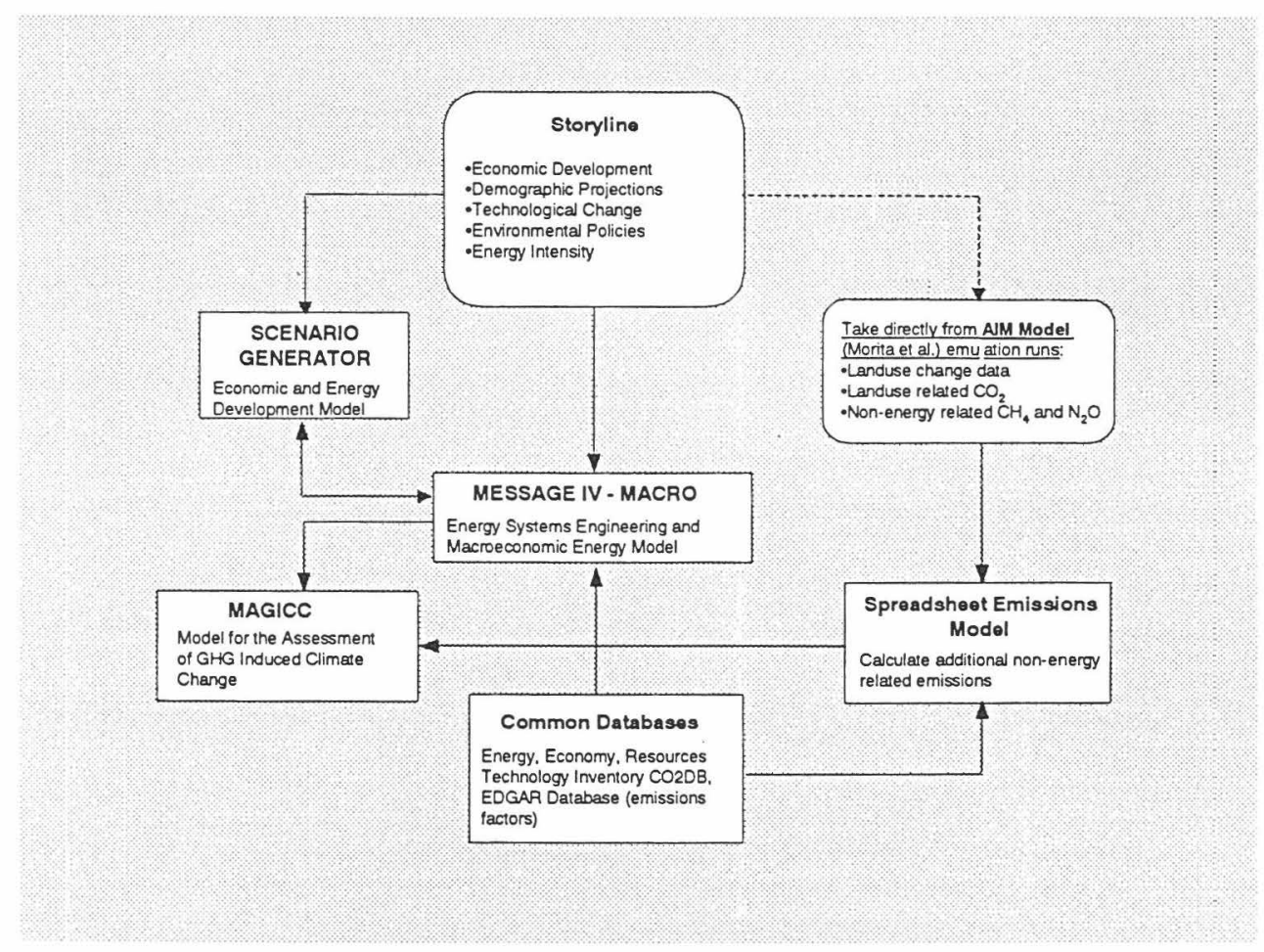

Fig. 13. The IIASA modeling framework used by the authors to quantify the scenarios presented in this paper 
minimizes total discounted energy system costs, and provides information on the utilization of domestic resources, energy imports and exports and trade-related monetary flows, investment requirements, the types of production or conversion technologies selected (technology substitution), pollutant emissions, and interfuel substitution processes, as well as temporal trajectories for primary, secondary, final, and useful energy. Important inputs for MESSAGE are technology costs and other technology parameters, which are taken from the energy technology database CO2DB. ${ }^{48}$

MACRO is a top-down macroeconomic model. Its objective function is the total discounted utility of a single representative producer-consumer. The maximization of this utility function determines a sequence of optimal savings, investment, and consumption decisions. In turn, savings and investment determine the capital stock. The capital stock, available labor, and energy inputs determine the total output of an economy according to a nested constant elasticity of substitution (CES) production function. Energy demand in two categories (electricity and non-electric energy) is determined within the model, consistent with the development of energy prices and the energy intensity of GDP. MACRO is linked to MESSAGE, and in an iterative fashion, internally consistent projections of realized GDP, and energy demand, that take price-effects into account.

To estimate aggregate climate impacts of the scenarios, we used Version 2.3 of the climate change model MAGICC. The model estimates net carbon flows and atmospheric $\mathrm{CO}_{2}$ concentrations, ${ }^{49}$ changes in radiative forcing and temperature relative to 1990, and sea level rise.

${ }^{48} \mathrm{CO} 2 \mathrm{DB}$ currently includes more than 1600 technologies and associated information on their recent, current, and projected costs, efficiencies, and environmental characteristics.

${ }^{49}$ MAGICC includes a carbon cycle model that relates atmospheric inputs (emissions) and outputs (physical and chemical sink processes) to changes in the atmospheric carbon concentration. It uses carbon dioxide $\left(\mathrm{CO}_{2}\right)$, methane $\left(\mathrm{CH}_{4}\right)$, sulfur dioxide $\left(\mathrm{SO}_{2}\right)$, and nitrogen oxide $\left(\mathrm{NO}_{x}\right)$ energy-related emissions from MESSAGE together with emission profiles for other greenhouse gases and non-energy related activities from the spreadsheet emissions model. 


\section{Appendix II}

Table 4. Aggregate technologies in the electricity generation sector

\begin{tabular}{|c|c|}
\hline Abbreviation & Technology Description \\
\hline CoalStdu & Coal power plant, no FGD, no DENOX \\
\hline CoalStda & Coal power plant, $90 \%$ FGD, $50 \%$ DENOX \\
\hline CoalAdv & $\begin{array}{l}\text { Advanced coal power plants; e.g., integrated gasification combined-cycle } \\
\text { (IGCC) }\end{array}$ \\
\hline FossilFC & Gas- and coal-based fuel cells \\
\hline Oil & Oil power plants \\
\hline GasStd & Gas power plant (standard steam cycle) \\
\hline GasCC & Gas combined-cycle power plant \\
\hline GasReinj & $\begin{array}{l}\text { Combined cycle power plant with no } \mathrm{CO}_{2} \text { emissions (re-injected for } \\
\text { enhanced oil recovery at field), efficiency reduced by } 1 \%\end{array}$ \\
\hline BioSTC & Biomass power plant (standard steam cycle) \\
\hline Bio_GTC & Biomass gasification power plant \\
\hline Waste & Waste power plant \\
\hline Nuc_LC & Conventional nuclear power plant, low costs, low efficiency \\
\hline Nuc_HC & Conventional nuclear power plant, high costs, high efficiency \\
\hline Nuc\&0-Carb & $\begin{array}{l}\text { Other advanced zero-carbon technologics (including high temperature } \\
\text { and fast breeder reactors) }\end{array}$ \\
\hline Hydro & Hydroelectric power plant \\
\hline SolarTh & $\begin{array}{l}\text { Solar thermal power plant with storage, and solar thermal power plant } \\
\text { for } \mathrm{H}_{2} \text { production }\end{array}$ \\
\hline SolarPV & Solar photovoltaic power plant (no storage) \\
\hline Wind & Wind power plant \\
\hline Geothrm & Geothermal power plant \\
\hline $\mathrm{H} 2 \mathrm{FC}$ & $\begin{array}{l}\text { Electricity from hydrogen fuel cells in the industry and the residential } \\
\text { sector, off-peak electricity production via hydrogen-based fuel cells in } \\
\text { the transport sector }\end{array}$ \\
\hline PV-ons & Photovoltaic onsite electricity production \\
\hline
\end{tabular}

Due to the high degree of technological detail in MESSAGE, it was not possible to report results for each individual technology 


\section{Ordering Information}

Orders must include the publication number and should be sent to the Publications Department, International Institute for Applied Systems Analysis, A-2361 Laxenburg, Austria.

Telephone: +432236 807

Telefax: +432236 71313

E-mail: molina@iiasa.ac.at

A full list of IIASA publications is available at www.iiasa.ac.at 
$\rightleftharpoons$ International Institute for Applied Systems Analysis

$\Longrightarrow$ Schlossplatz 1, A-2361 Laxenburg, Austria

$\Rightarrow$ Tel: +432236807 Fax: +43223671313

I I A S A www.iiasa.ac.at 